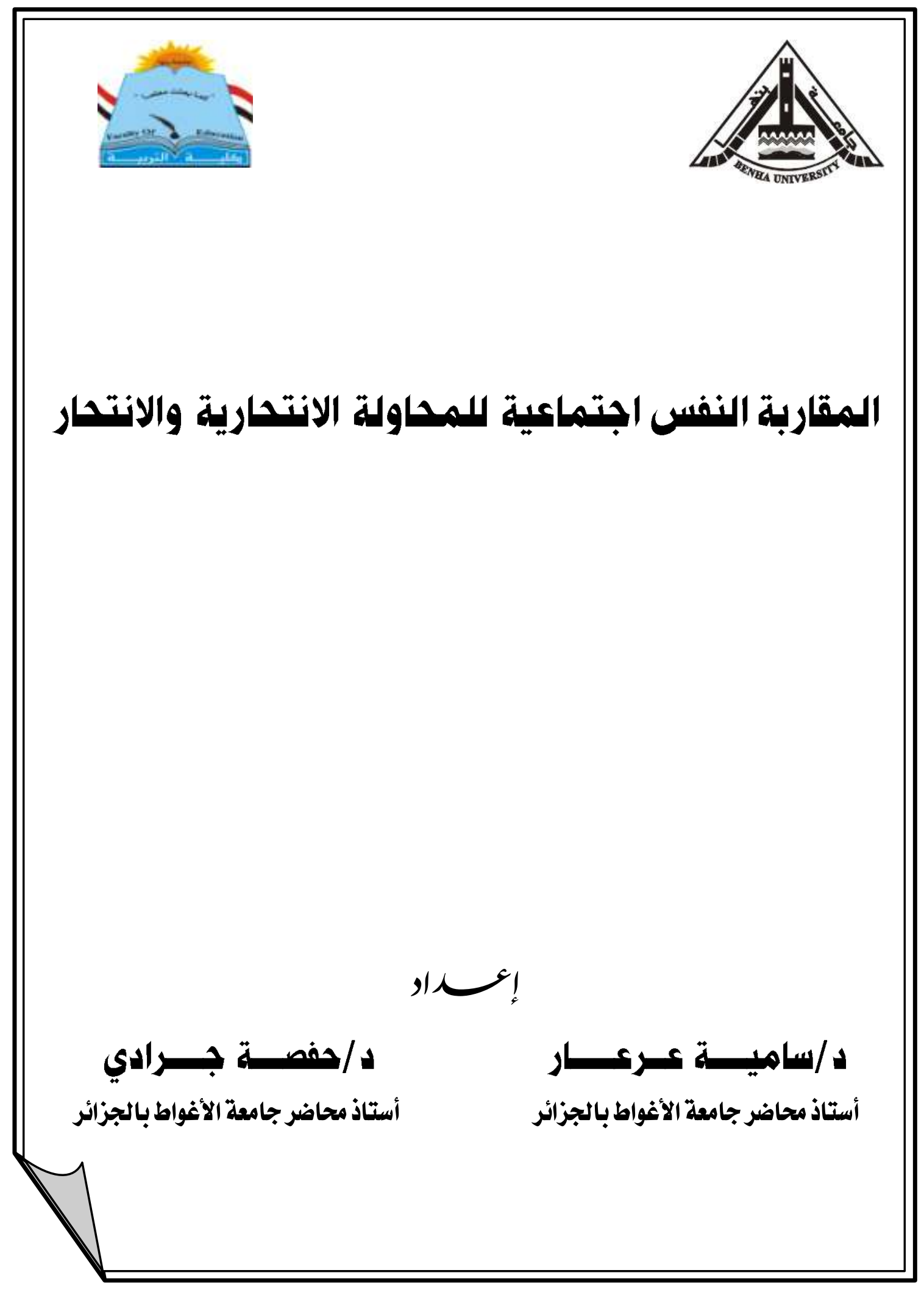




\section{المقاربة النفس اجتماعية للمحاولة الانتحارية والانتحار}

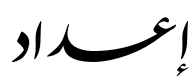

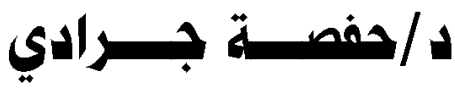

أستاذ محاضر جامعة الأغواط بالجزائر

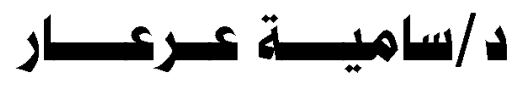
أستاذ محاضر جامعة الأغواط بالجزائر

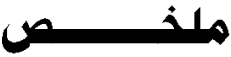

أصبحت المحاولة الانتحارية والانتحار ظاهرة مؤكدة من خلال الدراسات الأكاديمية

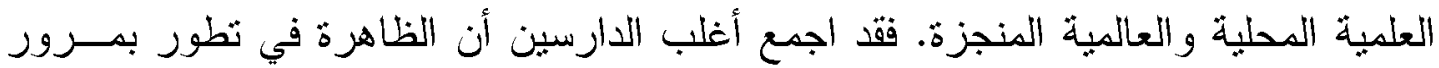
الزمن وأنها نتيجة لعو امل سوسيولوجية ونفسية وتغير ات تمس البنية الاجتماعية و الفرديــة . في هذا المقام تحاول الباحثنين رصد المحاولة الانتحارية والاتنحار من خلا طرح مفاهيهية

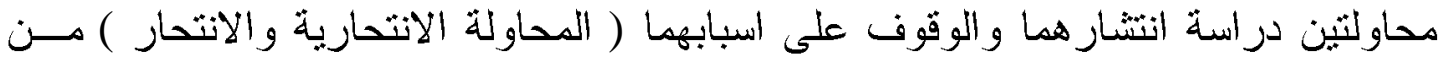
خلال بعض الدراسات العلمبة المنجزة لا سيما في الجزائر. و التي تناولت الظــاهرة محسل التهل العرض و ابراز بعض المحددات التي جعلت منها ظاهرة قابلة للار اسة. 
عرف سلوك الانتحار و المحاولة الانتحارية منذ فجر الإنسانية وقد درست كظــاهرة في كل المجتمعات ومن قبل كافة التخصصات الإنسانية ولفرط الاهتمام بفكرة الموت عموما وظاهرة الانتحار على وجه الخصوص اهندت بدراسة هذه المسألة علوم وتخصصات عسدة الخدان

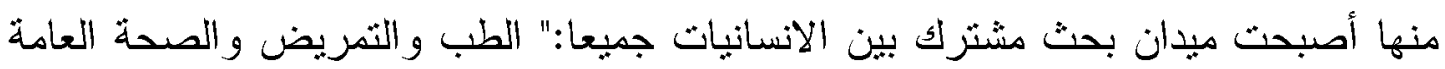

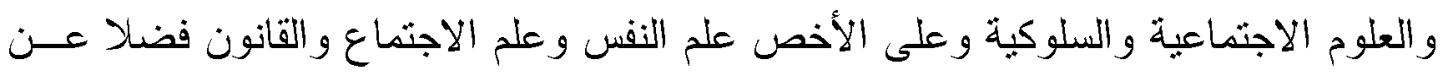

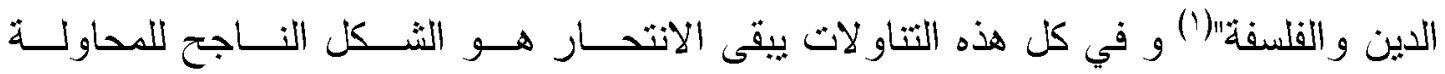

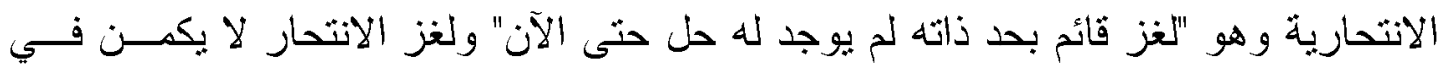

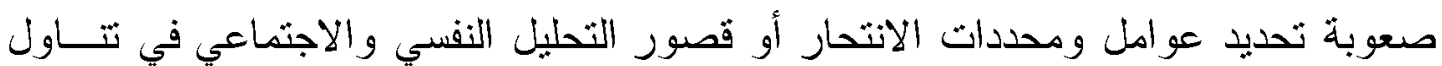

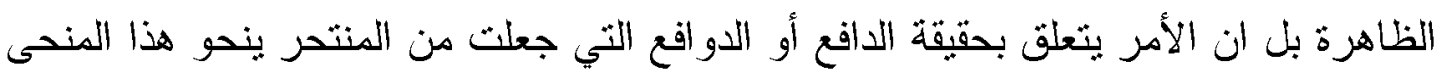

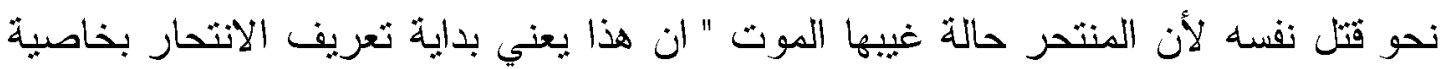

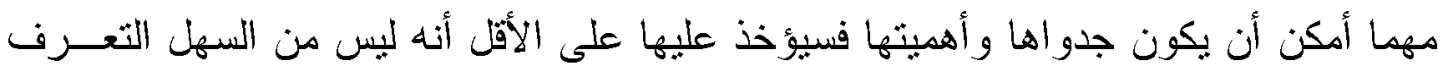

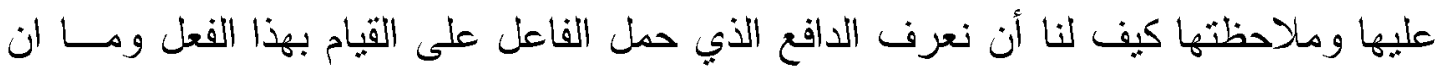

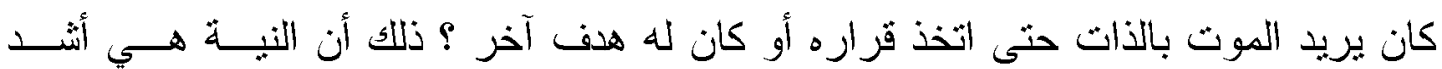
صميمية من أن نتمكن من الوصول اليها ومعرفتها من الخارج اللهم الا عبر تخمينات نقريبية

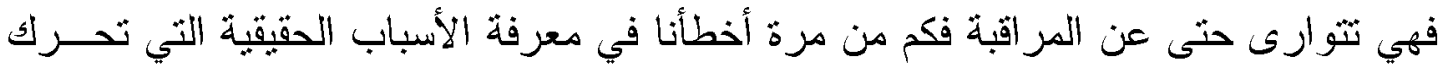

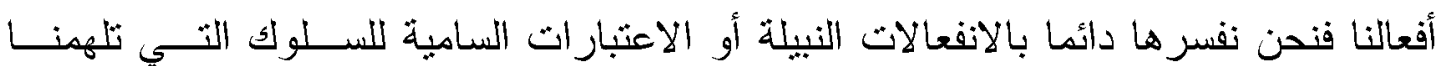

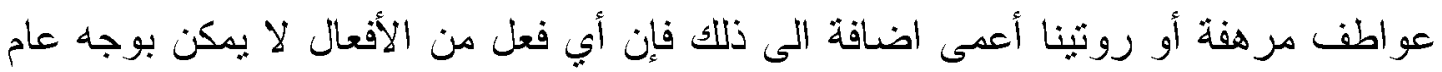

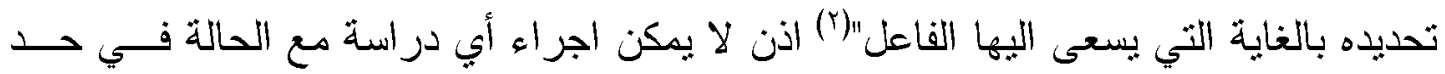

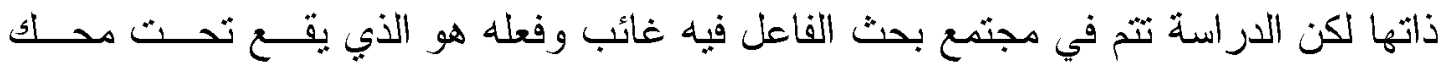

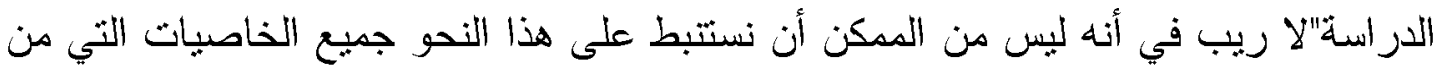

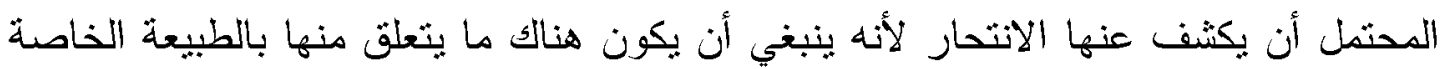

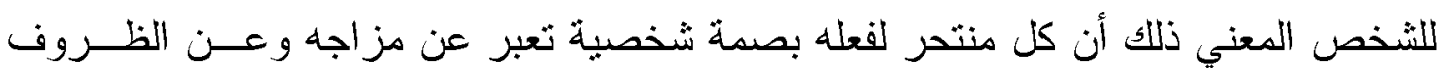

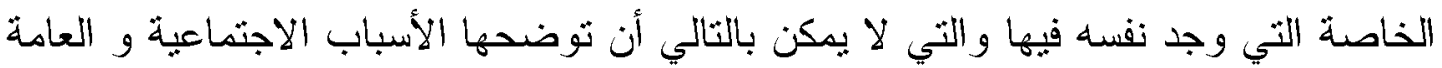

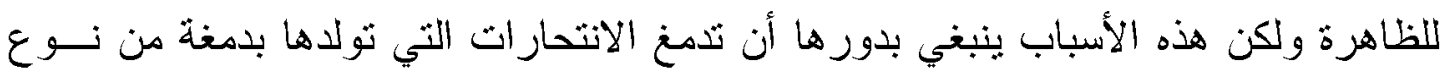

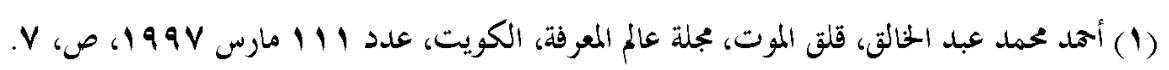

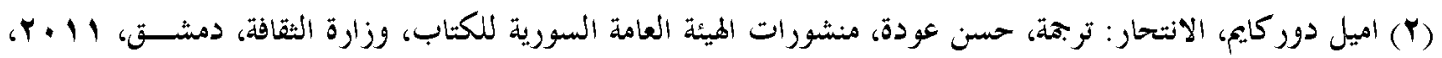


خاص بعلامة خاصة تحدد هذه الاتتحار ات ذلك أن هذه العلامة المشتركة هي التــي يعنينــا العثور عليها. من المؤكد فوق ذلك بأن هذه العملية لا بمكن انجاز ها إلا بدقة تقريبية فــندن

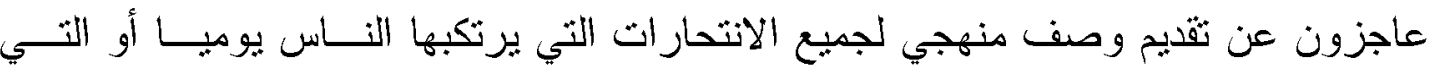

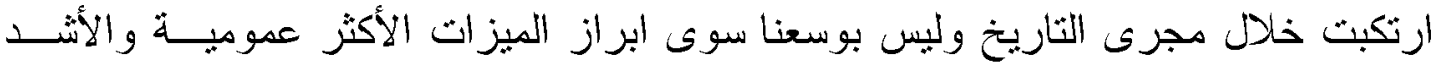

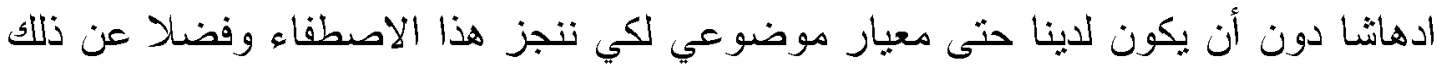

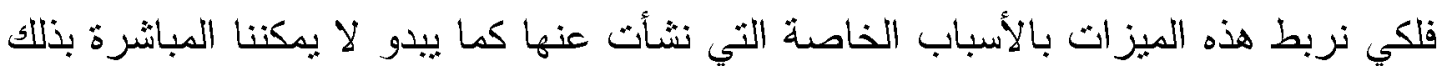

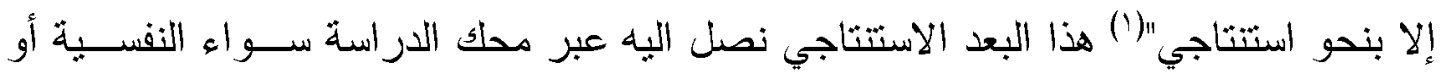
الاجتماعية ولكل تخصص اتجاه معين يتتاول به طبيعة الانتحار فالاتجــاه النفسـي يتتــاول المنتحر في حالة انفردايته و انعز اليثه بينما الاتجاه الاجتماعي ينتاول الظاهرة من خلال الميل

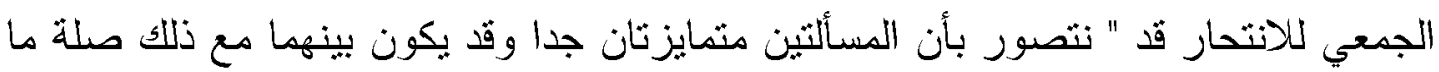

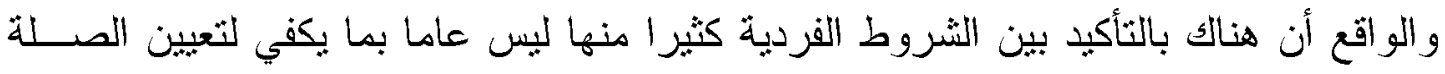

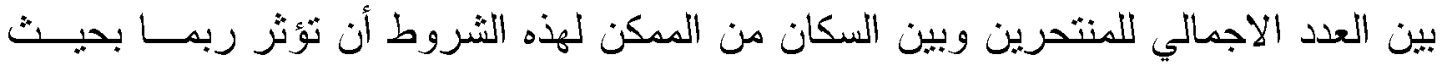

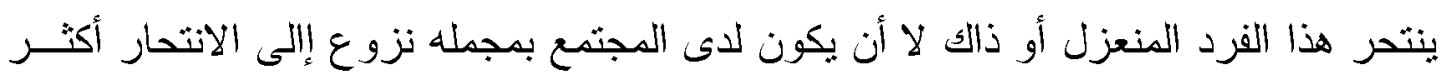

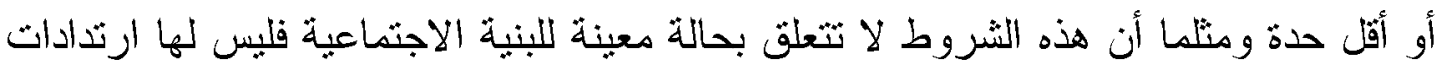

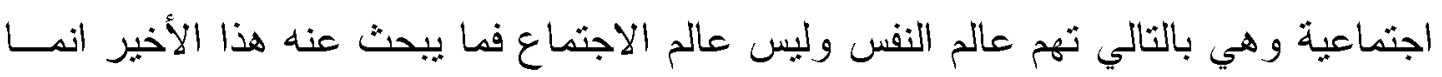

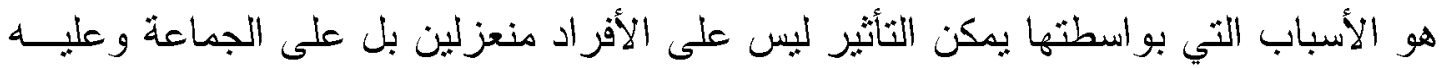

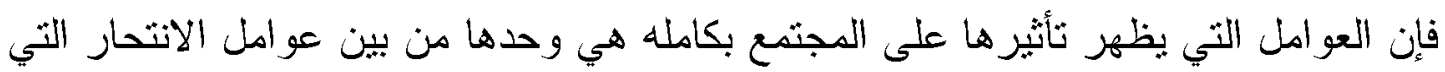

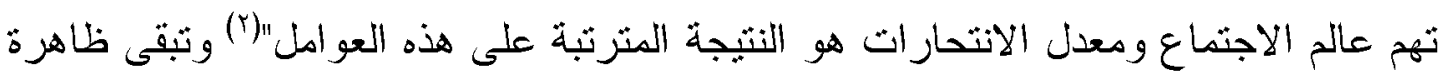

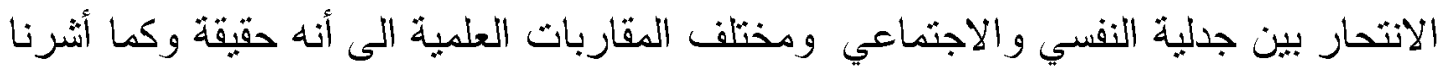

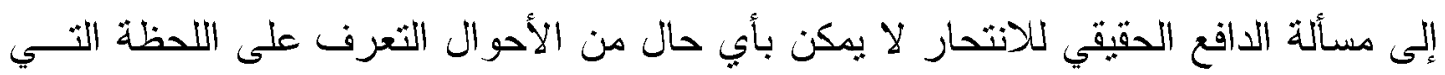

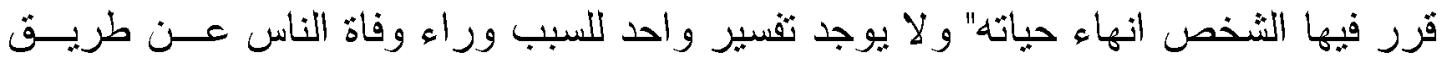

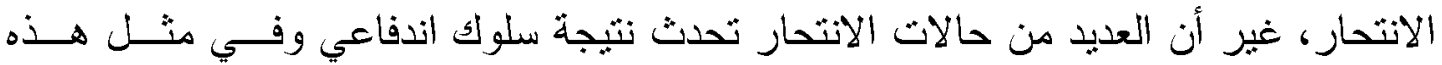

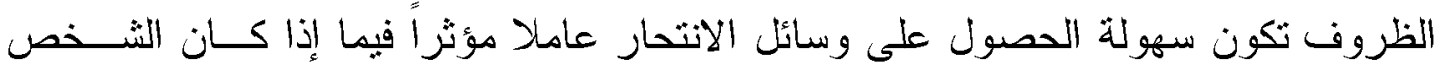

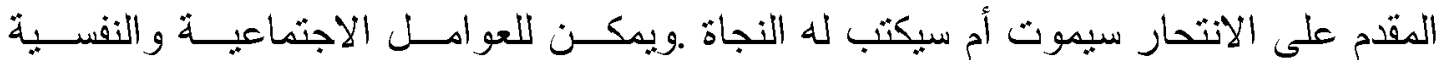

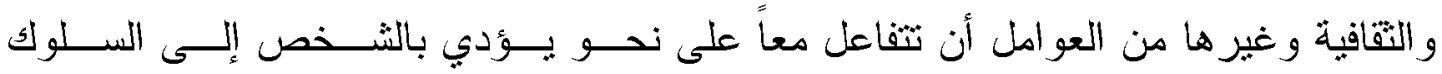


الانتحاري، إلى أن الوصم المرتبط بالاضطر ابات النفسبة والانتحار تعني أن العديد من الناس

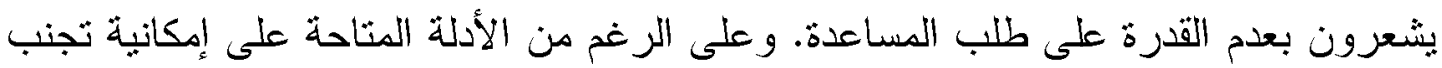

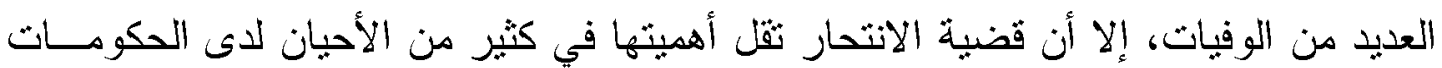

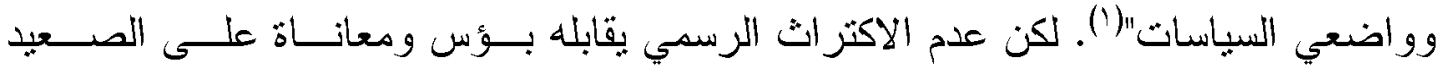

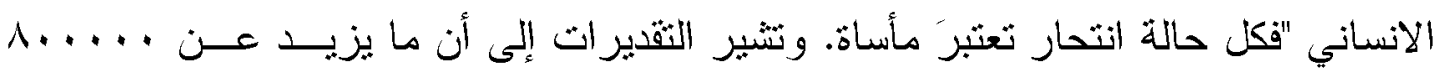

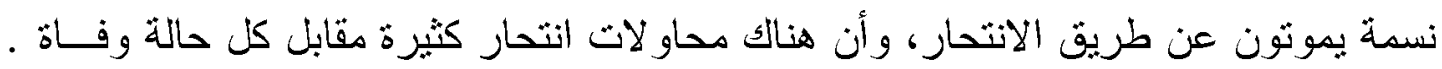

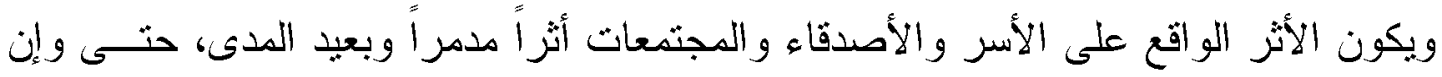

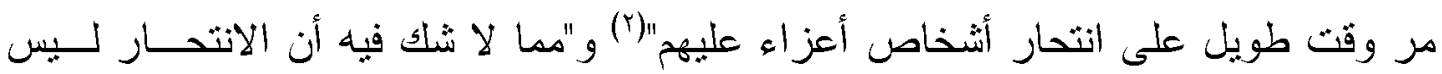

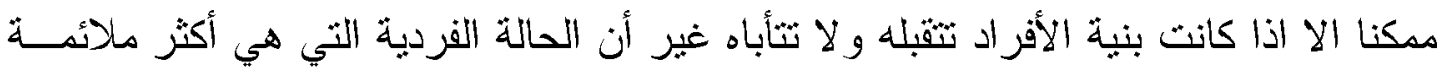

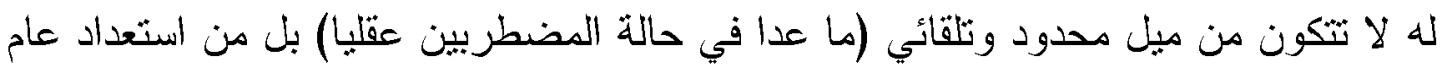

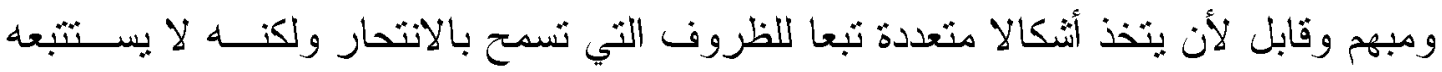

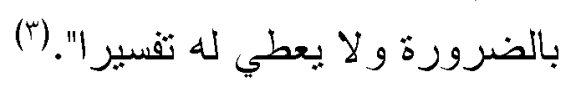

\section{ا- تدديد مفهومي الانتحار والمحاولة الانتحارية:}

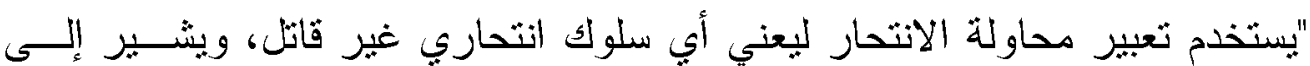

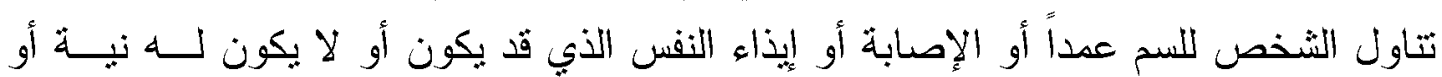

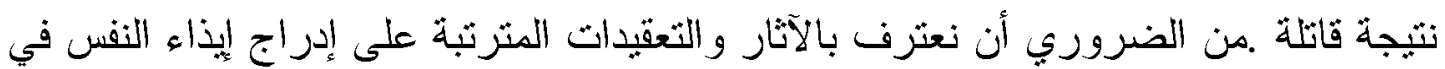

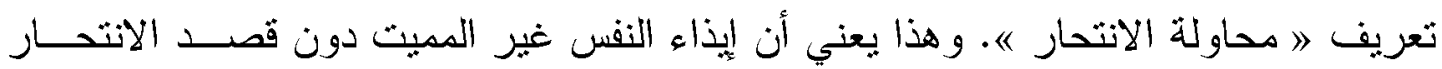

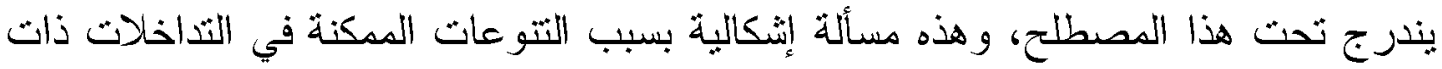

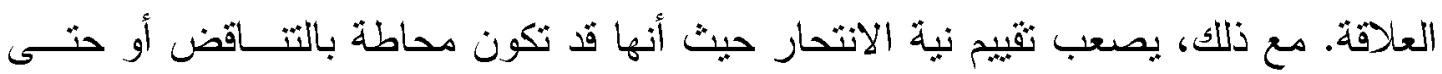

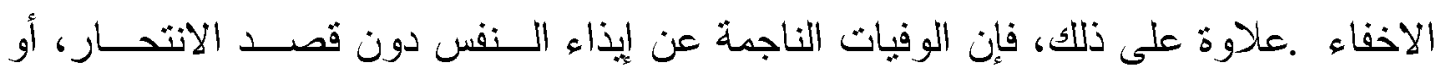

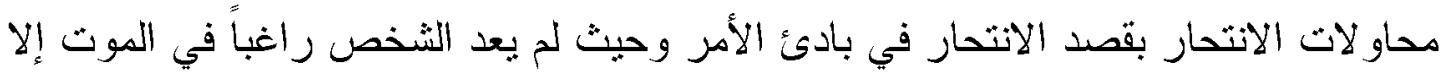

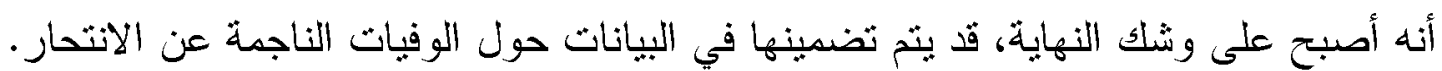

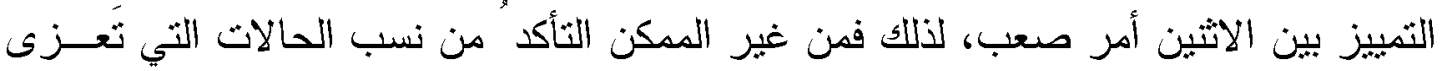

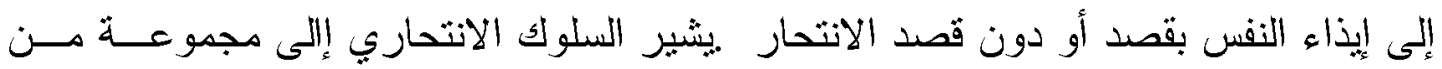

$$
\begin{aligned}
& \text { (1) منظمة الصحة العالمية، الوقاية من الانتحار: ضرورة عالمية، المكتب الاقليمي لشرق المتوسط، ع ا بr،ص، V. }
\end{aligned}
$$

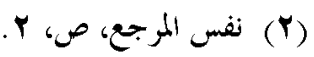

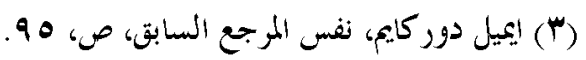




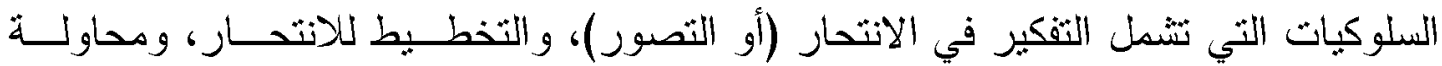

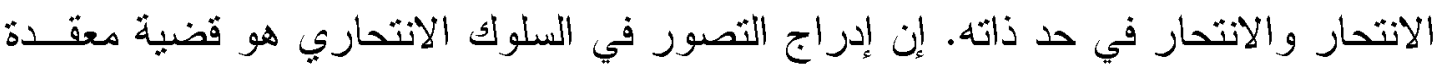

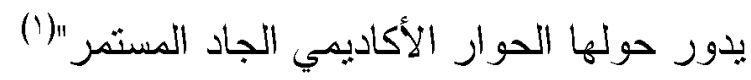

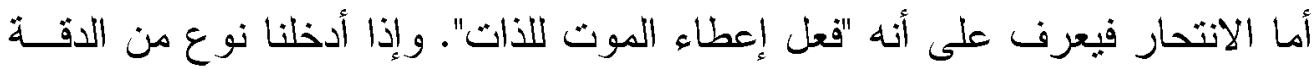

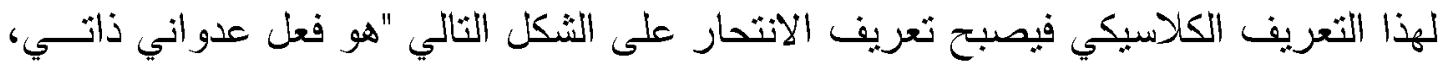

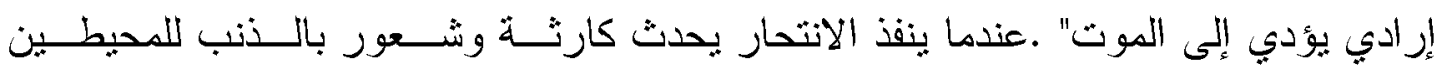

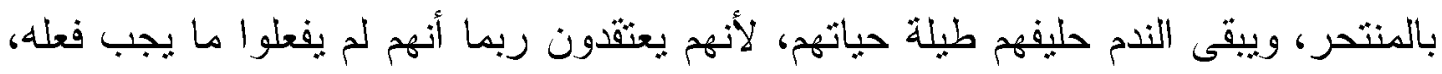

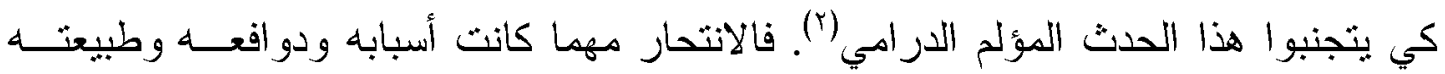

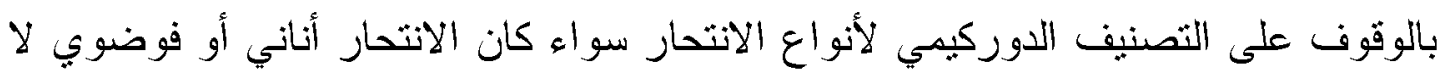

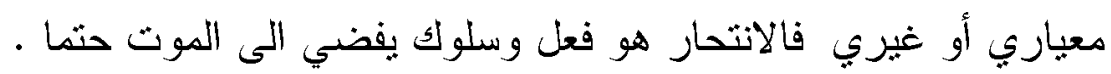

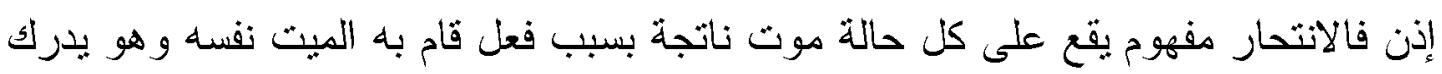
تمام الإدر الك أن الفعل يؤدي به إلى الفى الوفاة.

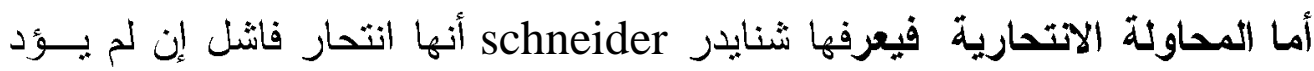
إلى الموت، وهذا مهما كان سبب الفتل سواء عن طريق تدخل شخص آنس آخر أو علاج ناجح.

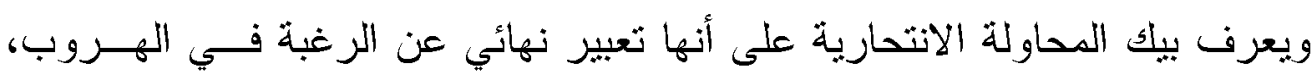

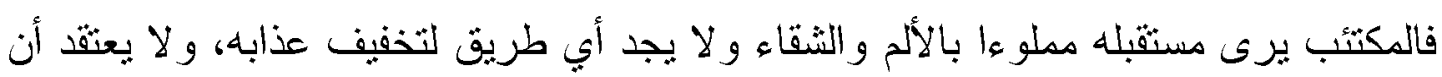

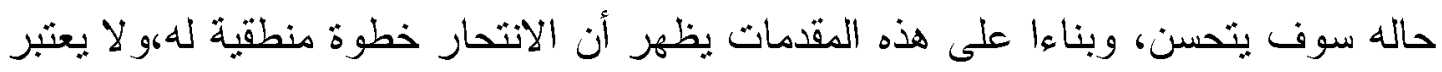

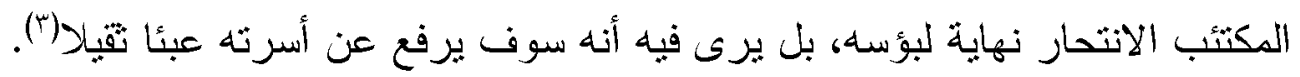

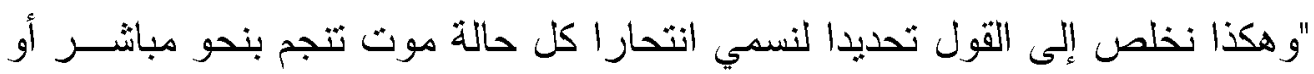

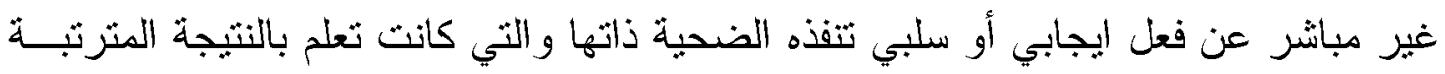

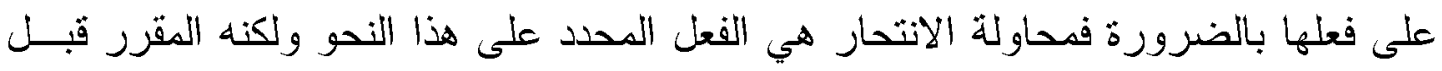

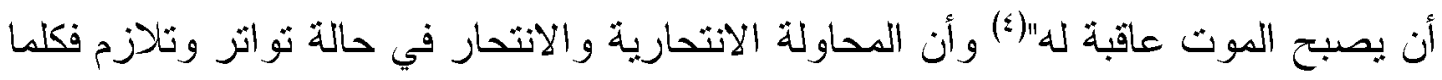

$$
\text { (1) (1) منظمة الصحة العالمية، نفس المرجع السابق، ص، +1 (1) }
$$

(2) BENSMAIL B. et al، «Suicides et conduites suicidaires en milieu maghrébin»، in

Revue de l'information psychiatrique، vol.66، décembre، Privat، 1990..p.990

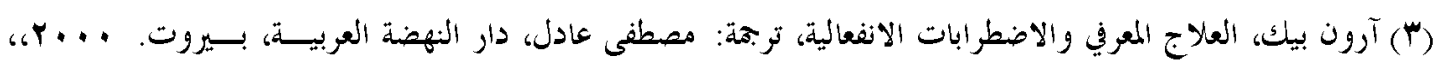


كان الاتنحار موجودا في بيئة اجنماعية ما بكون معدل المحاولة الانتحارية نفسه ومثتاســب

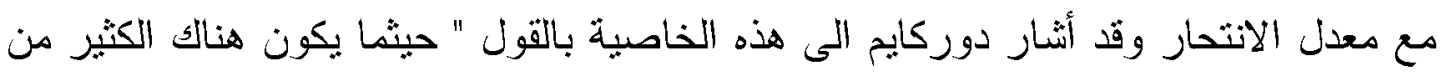

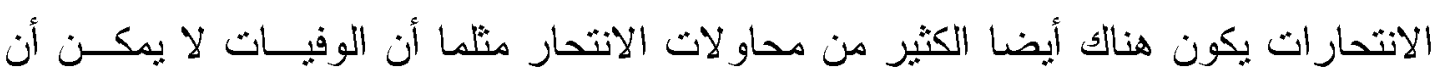

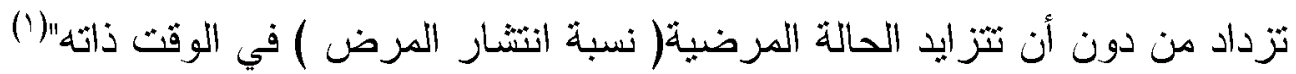

\section{ا - معطيات وبائية عن الانتحار والمحاولة الانتحارية:}

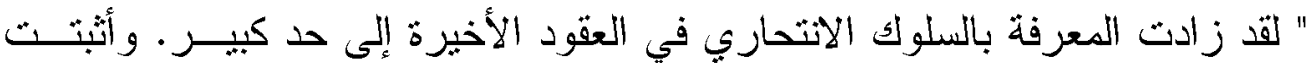

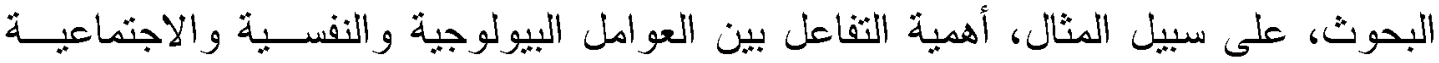

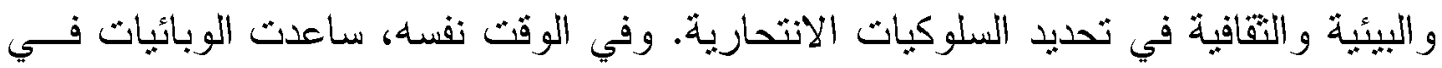

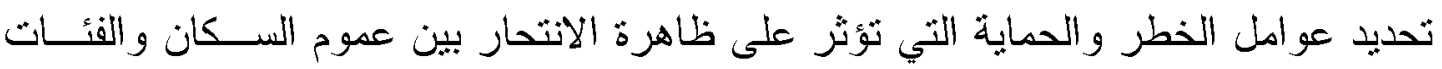

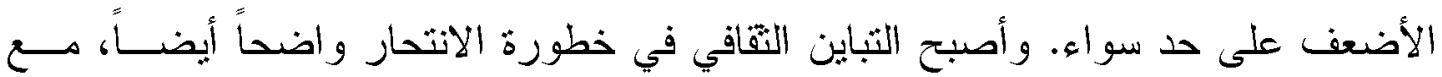

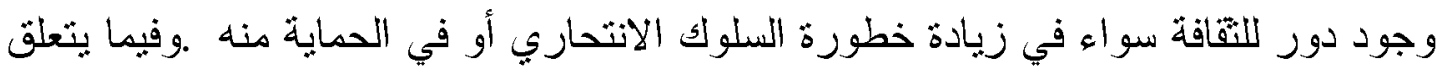

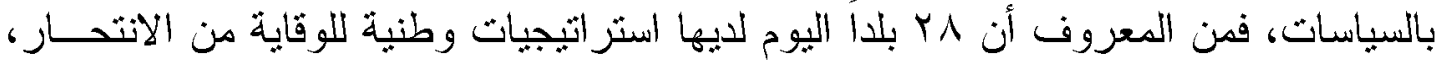

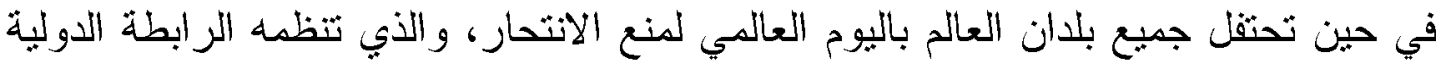

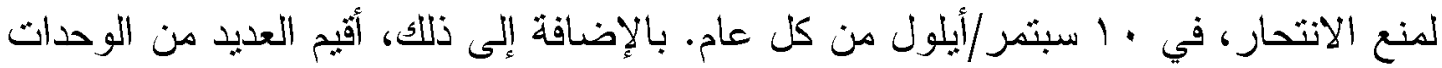

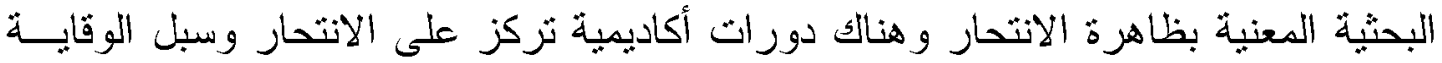

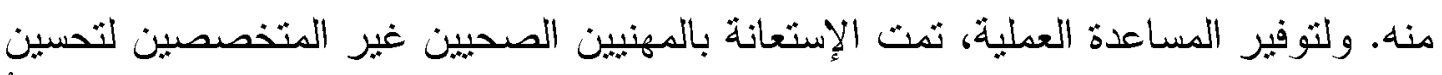

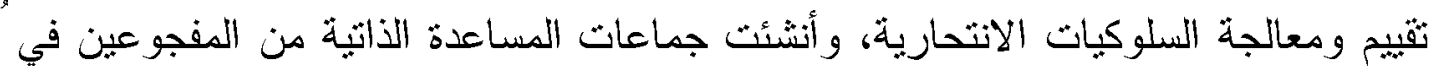

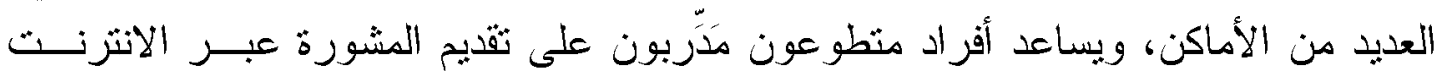

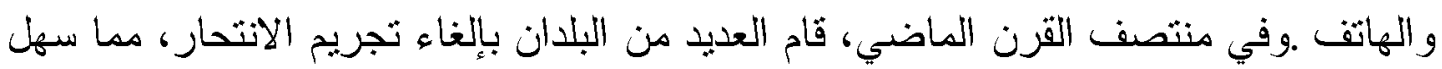

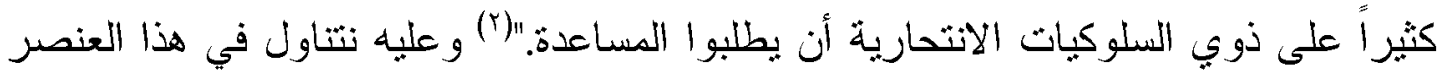

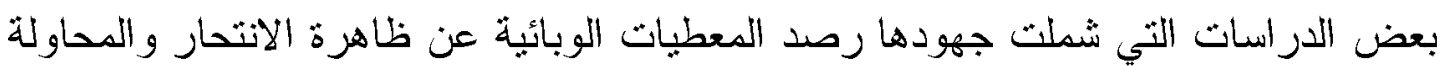

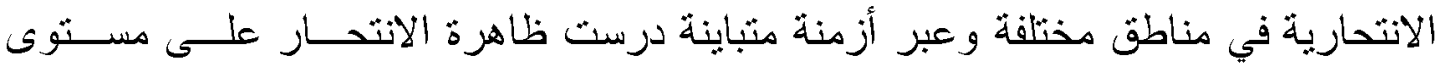

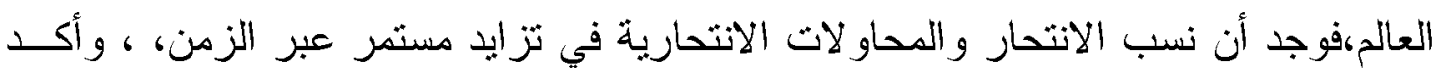

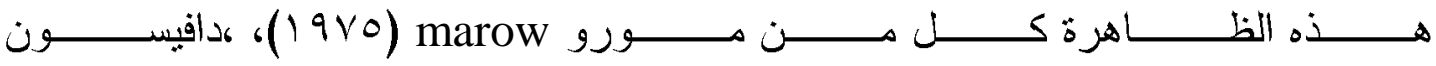
(191) davison (19ahyaoui 
وقد تأكد الباحثون في تخصصات متتوعة (الطـب الاجتـــاعي الطـب النفسـي،

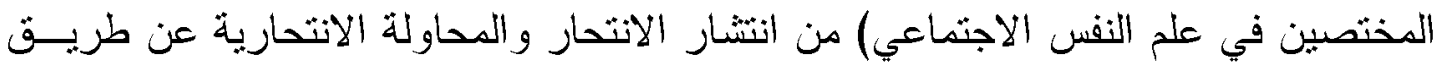

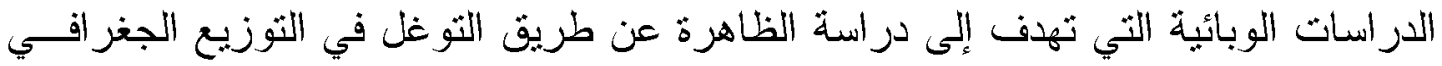
للانتحار وتطورها خلال الزمن ضمن عبنة محددة وهذا قصد تجنب مختلف العو امل التـي

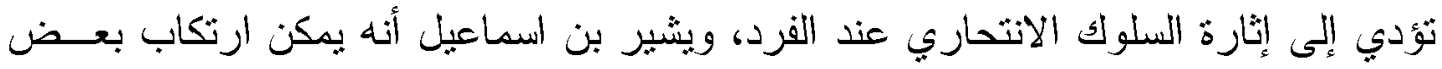

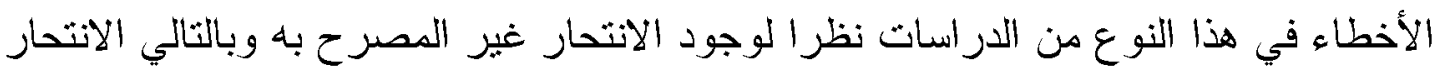
غبر المسجل بسبب العوامل العاطفية والدينية لاسبما في المجتمعات الإسلامية فهناك " حقيقة

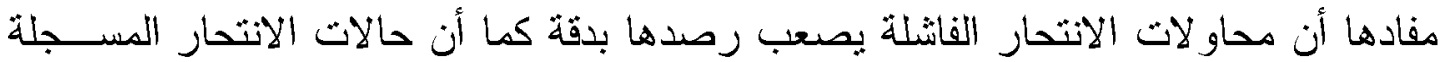

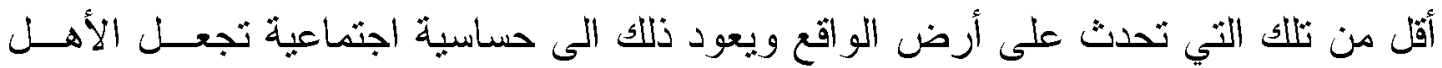

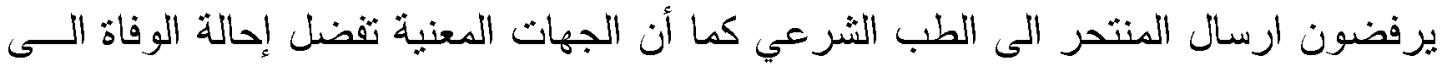

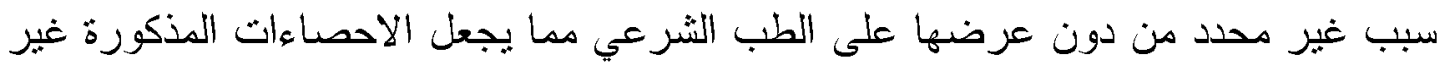
دقبقة بما فبه الكفاية"(1)

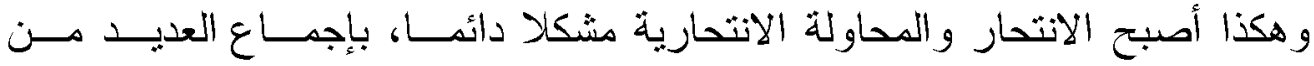

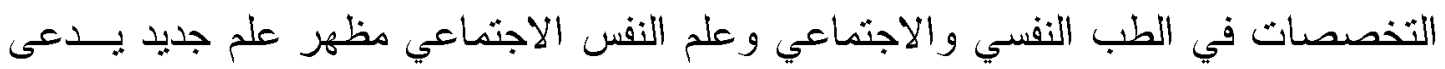

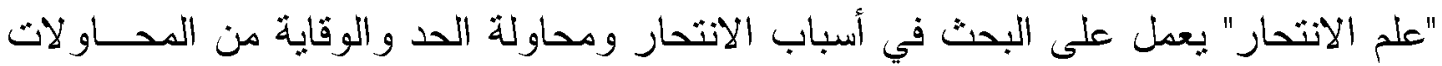

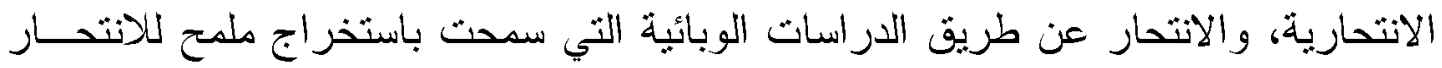

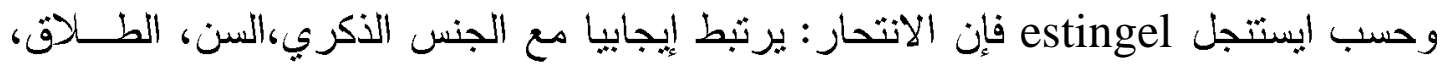

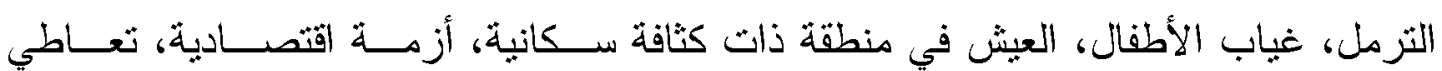

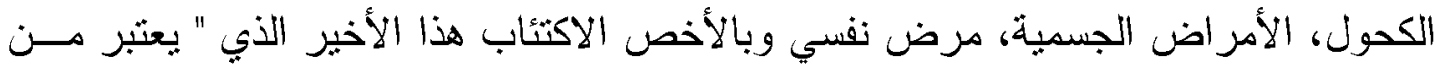

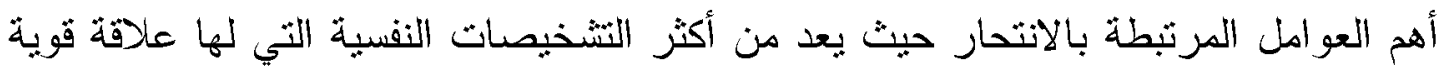

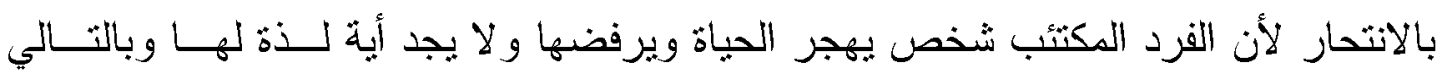

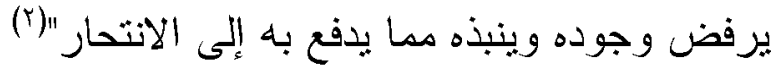

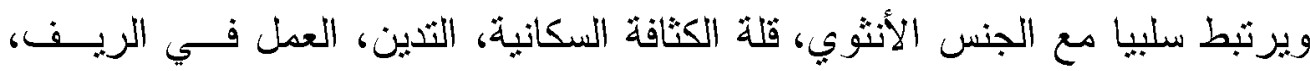

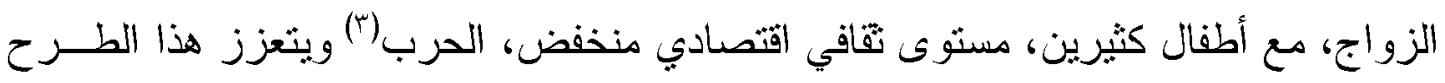

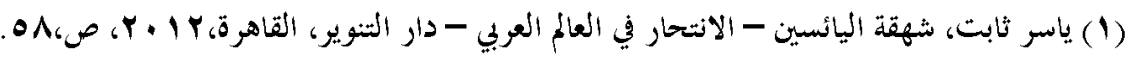

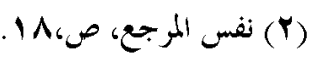

(3) Bensmail.op.cit.p.991،

\section{rTV}


مع ما جاء به دور كايم في دراسته لظاهرة الانتحار حبث يرى أن معدل الانتحار لا بــزداد

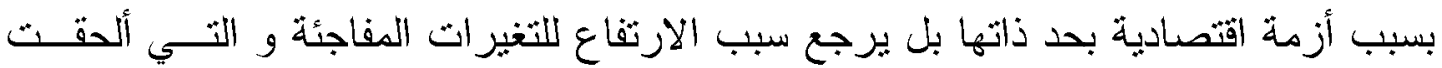

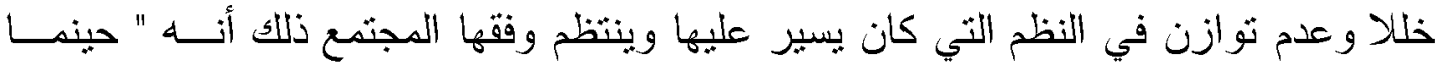

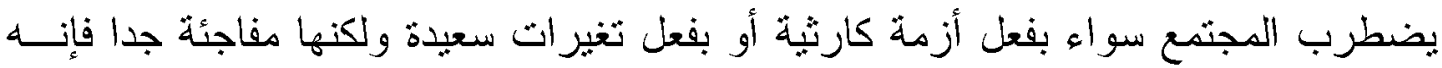

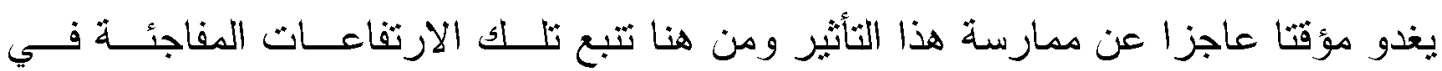
المنحنى البياني للانتحار ات "(1)

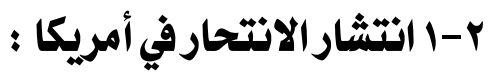

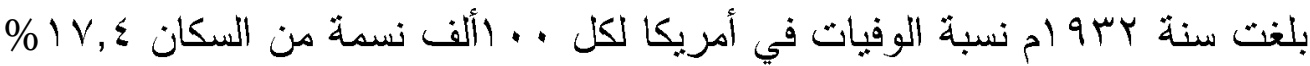

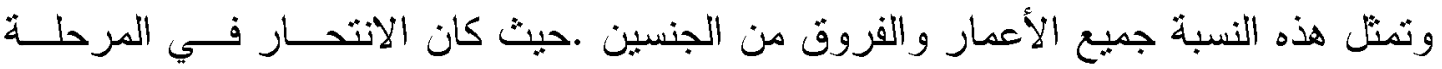

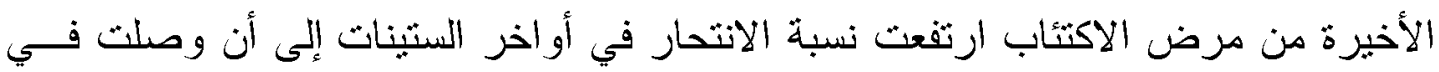

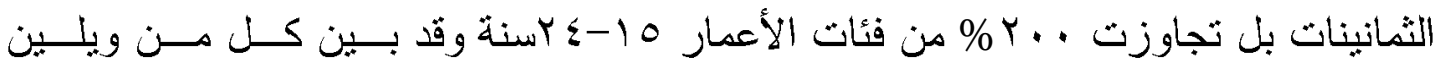

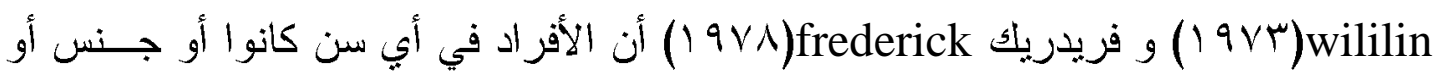

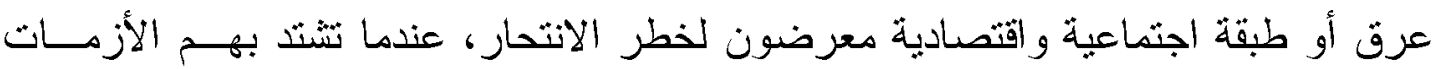

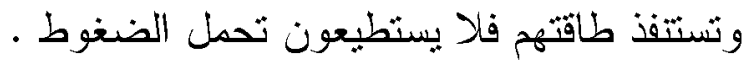

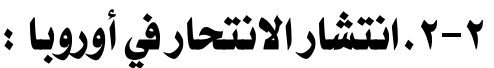

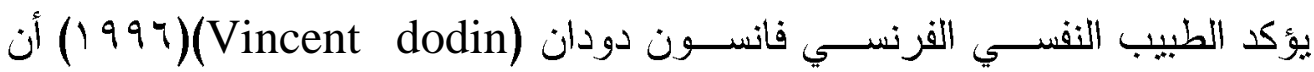

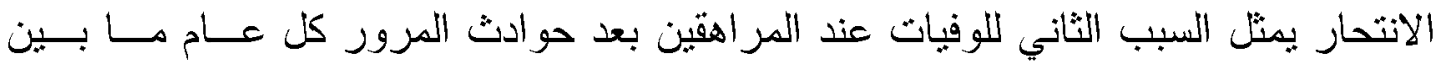

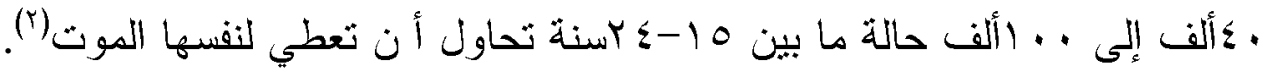

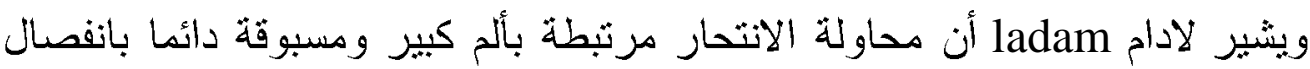

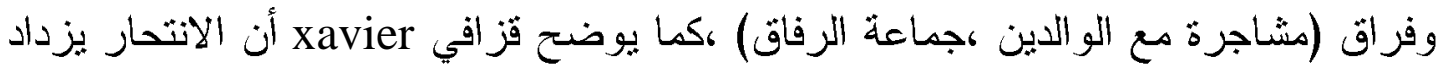

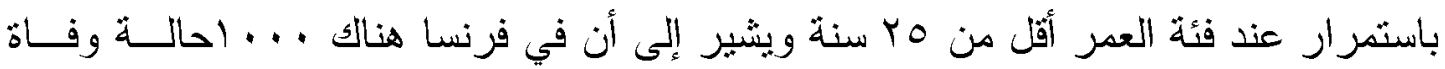

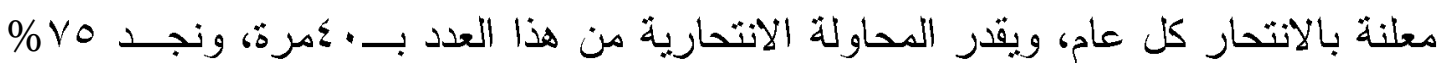

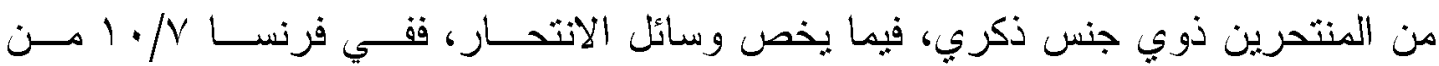

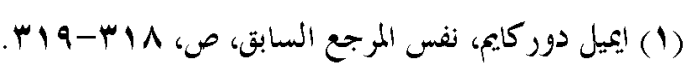

(2) Andries et al" suicide et conduite à risque" in revue pratique de psychologie de la vie sociale et d'hygiène mentale n.1, 42e année Fédération des associations d'aide à la santé mentale, France 1996.p.27 . 
المنتحرين بستعكلون سلاح ناري لقتل أنفسهم، و •9\% بستعملون الأدوية، ويزداد الخطر بعد

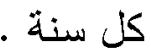

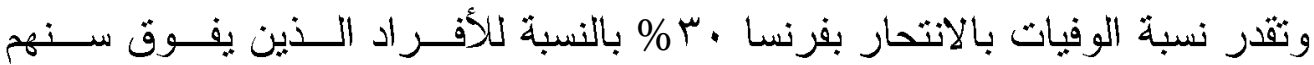

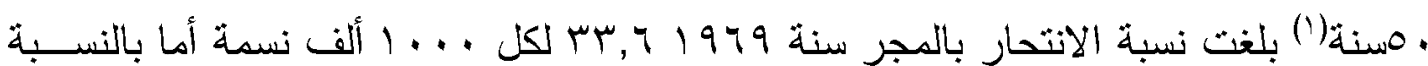

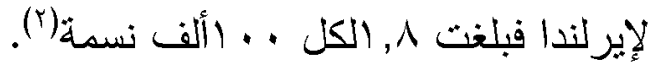

\section{ع.انتشار الانتحار في المنطقة المفاربية :}

قبل التطرق إلى نوضيح انتشار الاتنحار و المحاولة الانتحارية في الوسط المغــاربي

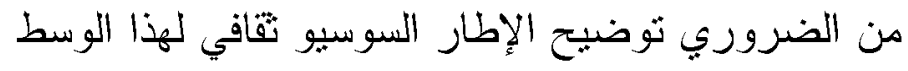

1-1 وضعية الدين :

ان تأثثر البعد الايني الروحاني للإسلام في تصور الموت بشكل عام بعطي قداســة

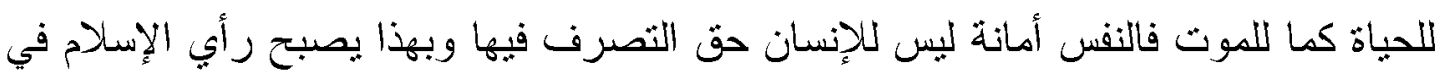

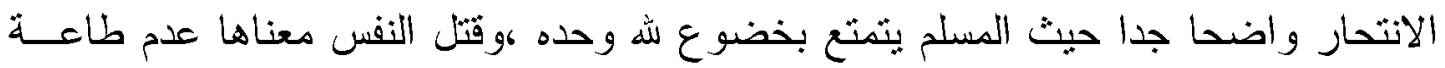

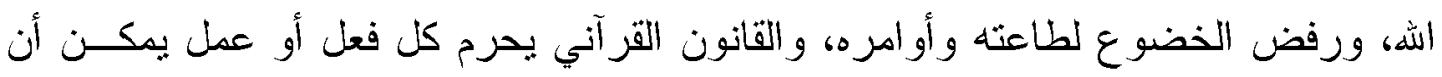

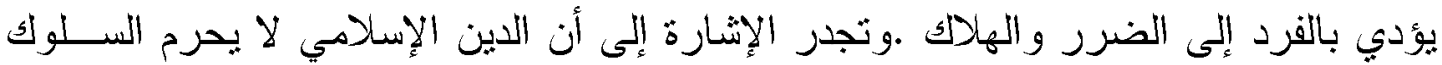

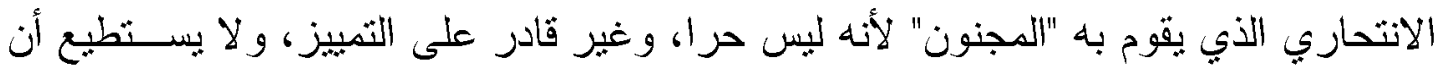

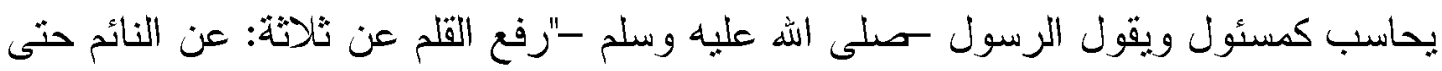

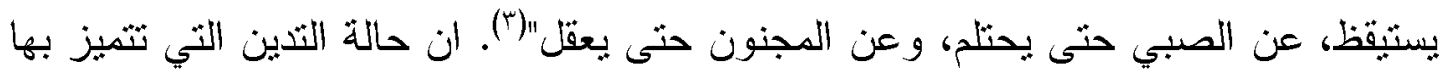

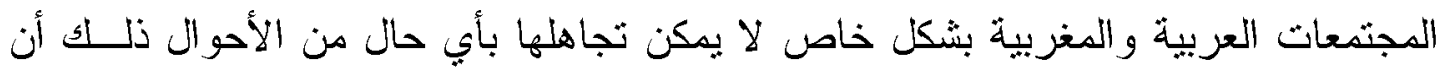

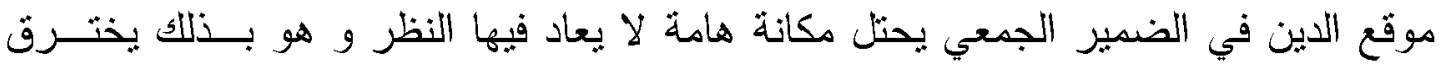

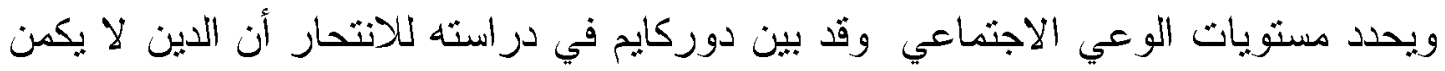

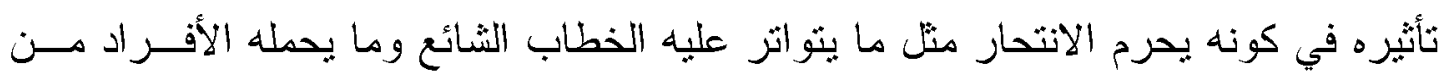

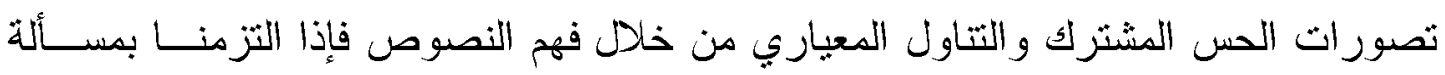

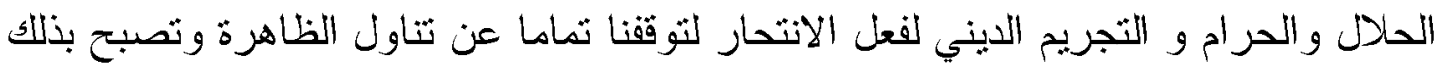

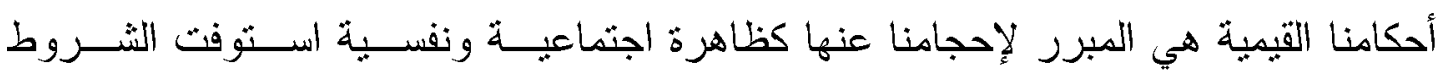

(1) Bensmail op.cit.p.994

(2) Ibid.p.991

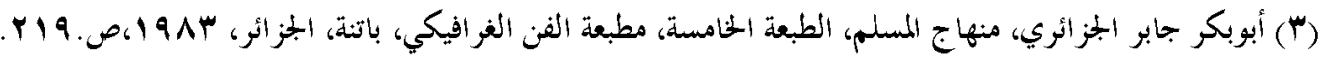


الموضوعية لدراستها و التحقق منها بل أن قوة الخطاب الديني تكمن في القهر الذي بمارســـ

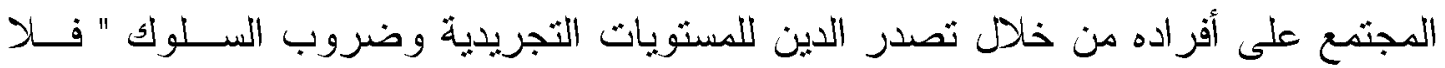

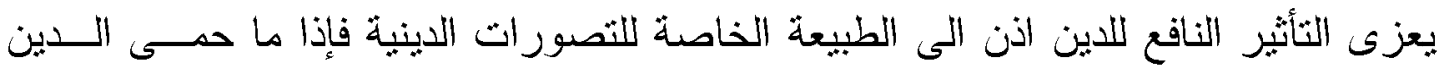

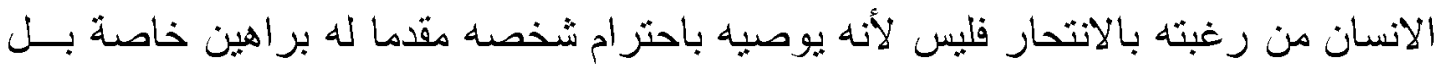

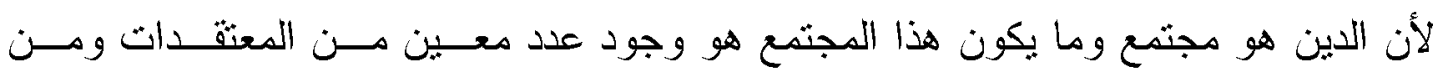

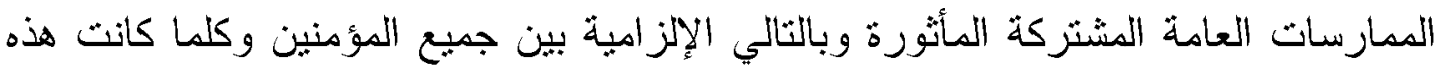

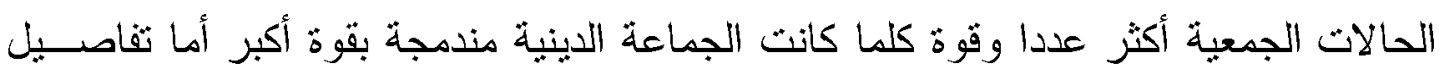

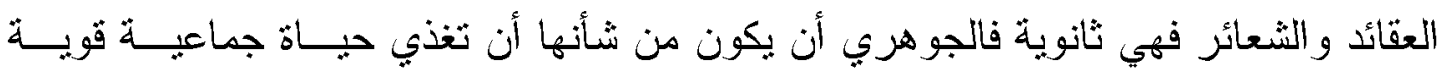
ومنينة بنحو كاف"( (1)

ولهذا يقل الانتدار في المجتمع المغربي التقلبدي وهذا يفسر بالدين الإسلامي الــذي

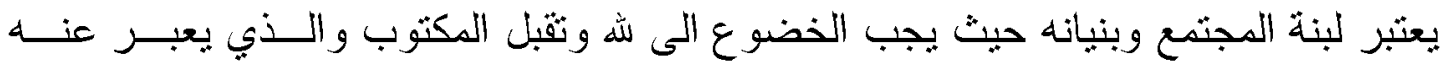

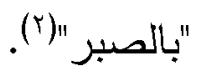

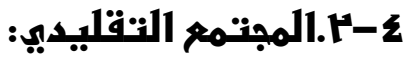

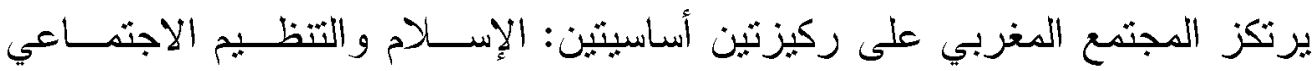

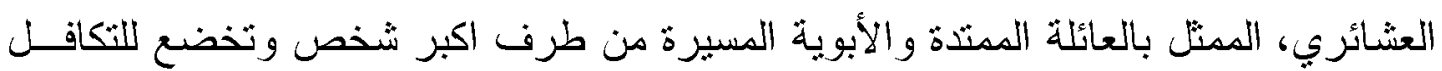

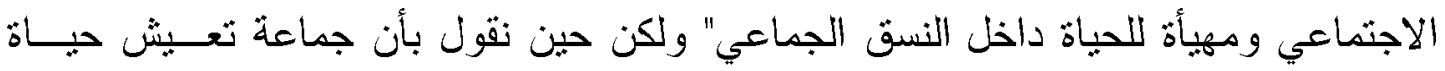

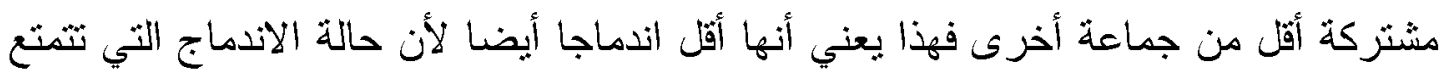

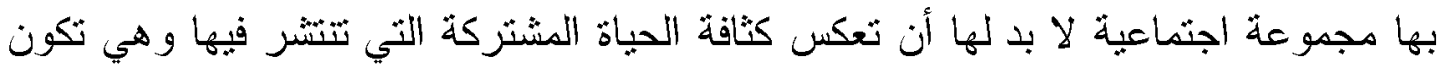

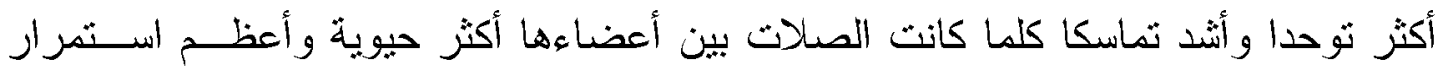

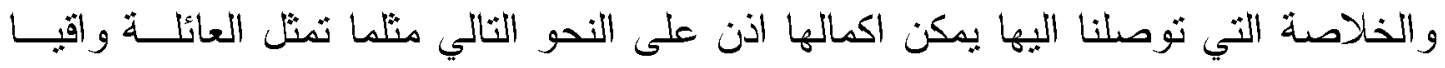

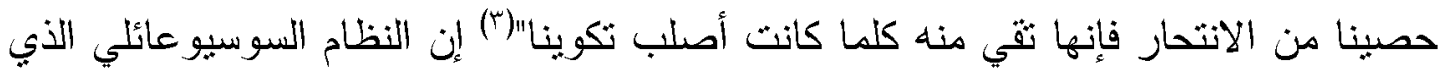

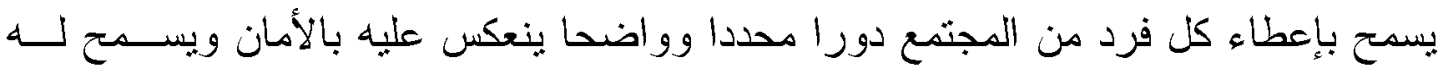

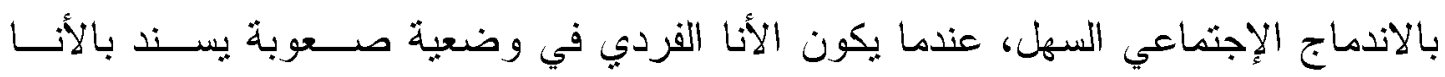

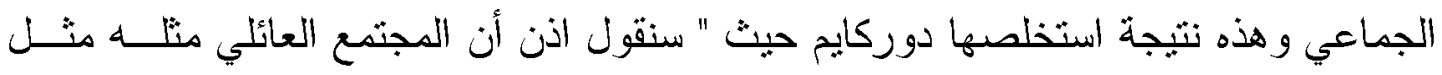

(2) Bensmail op.cit.p.991

(1) ايميل دور كايم، نفس المرجع السابق، ص، 199.

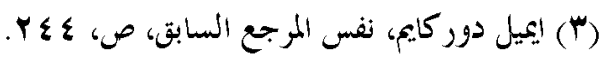


المجتمع الديني يقي من الانتحار"(() اذن هاتين الخاصيتين تلثقبان بإمتياز في المجتمع العربي

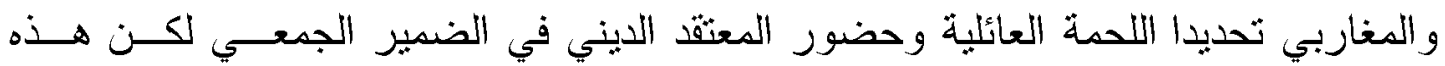

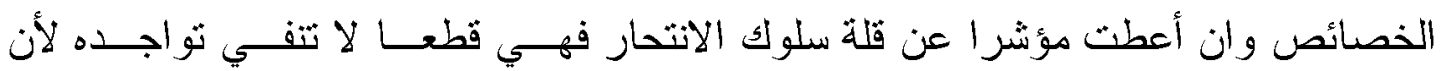
الاحصائيات و الدراسات الني تتاولت ظاهرة الانتحار لم نستنتي المجتمعات التي يقوم نظامها

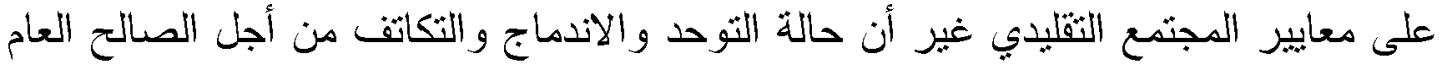

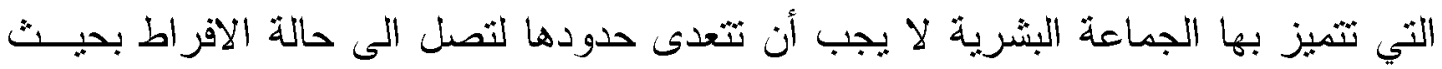

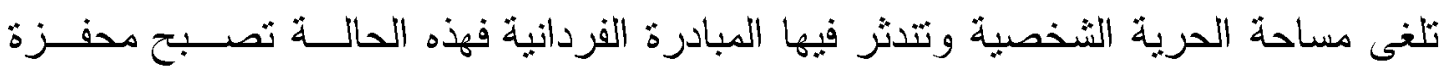

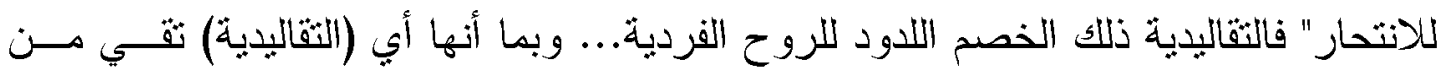

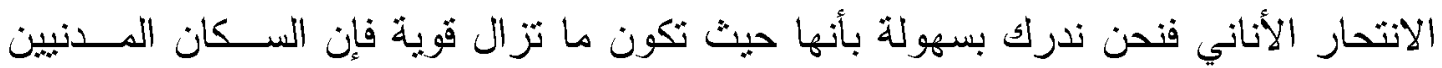

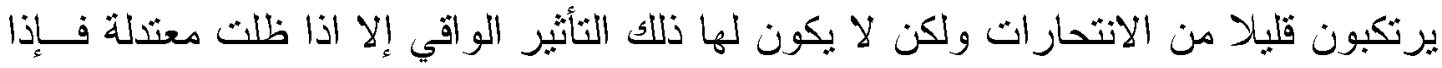

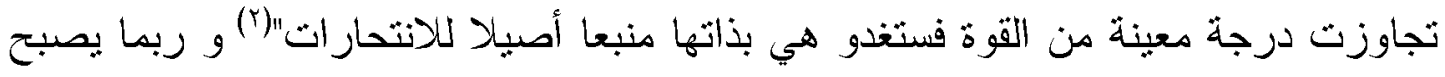

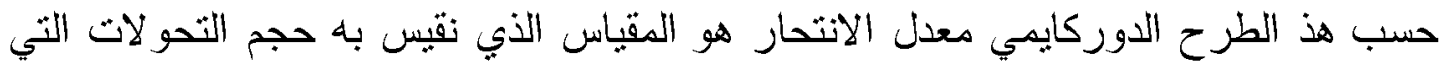

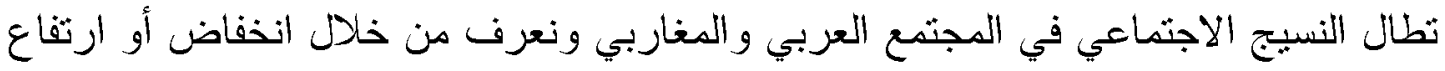

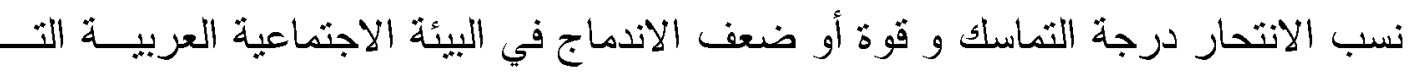

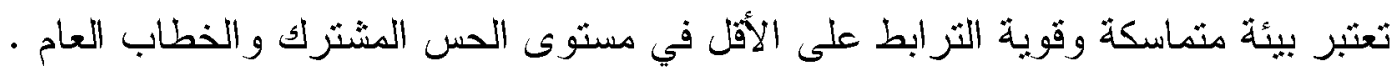

\section{؟-ץ-التفيرات الاجتماعية ومظاهر التثاقف في المجتمع المفاربي:}

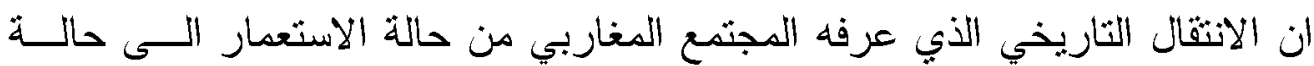
اللاستعمار لا شك قد سدت بثغير اجنماعي وتحو لات جوهرية خضعت لمنطق الانفصـال

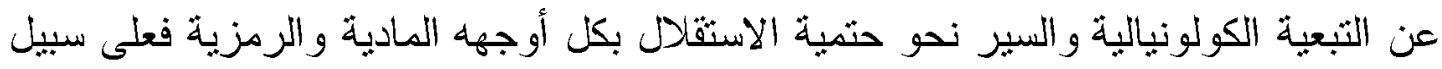

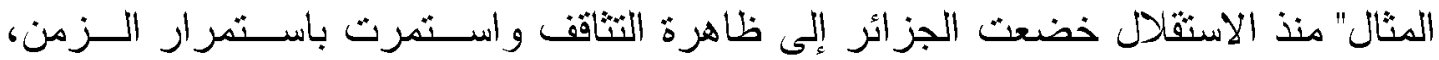

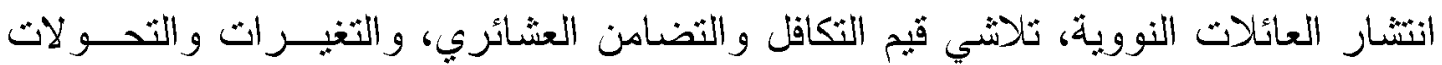
السوسيو إقتصادية والثقافية كالتصنيع، النزوح الريفي، التمدرس الكثبف، كل هذه العوامـل

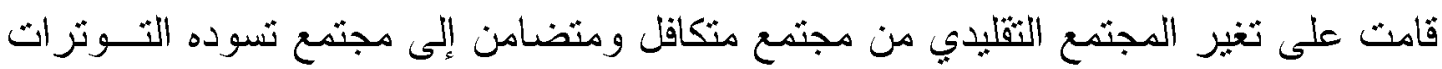

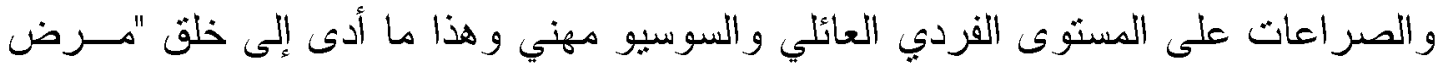




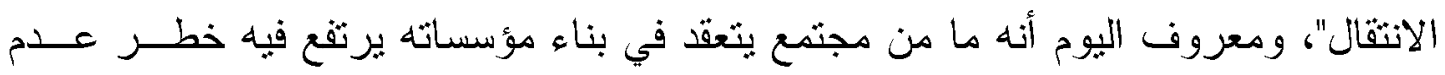

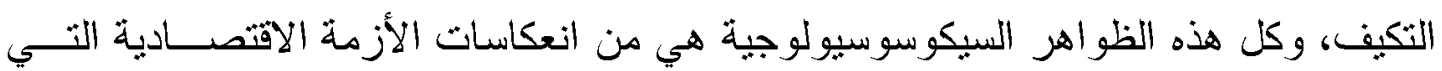

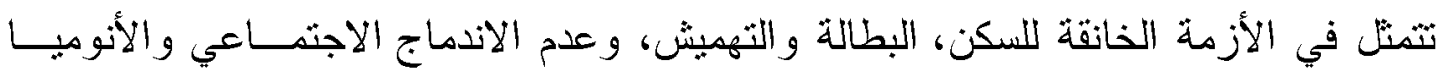

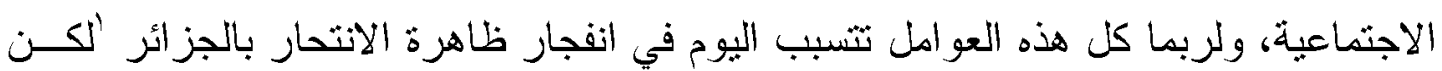

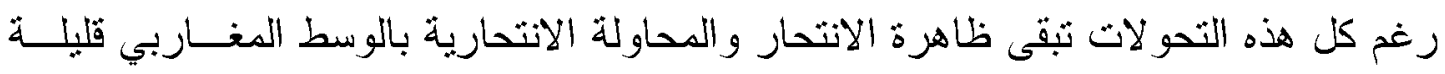

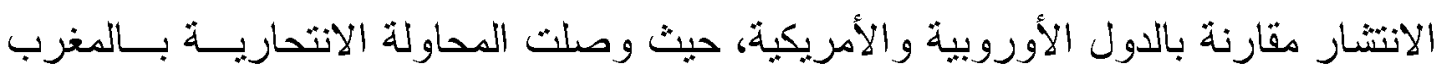

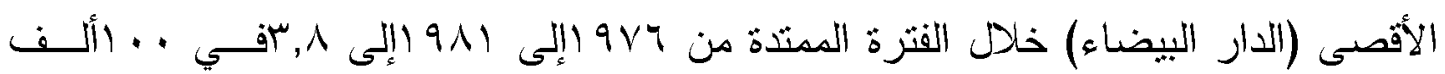

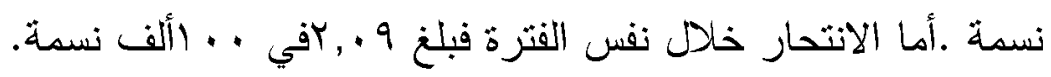

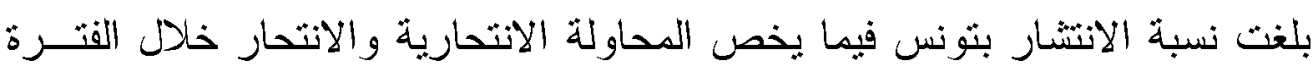

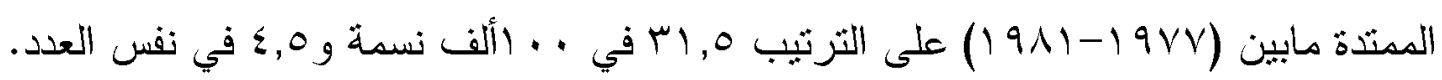

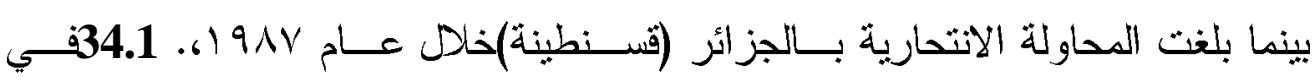

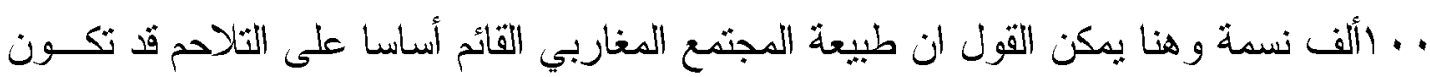

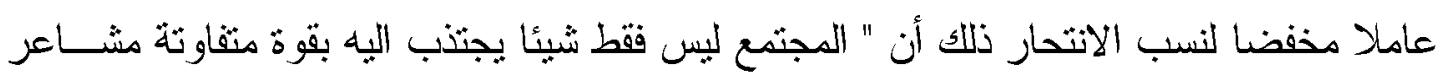
ونثاطات الأفراد فهو أيضا سلطة تنظم هذه المثاعر و النشاطات وتضبطها وثمة صلة ثربط بين

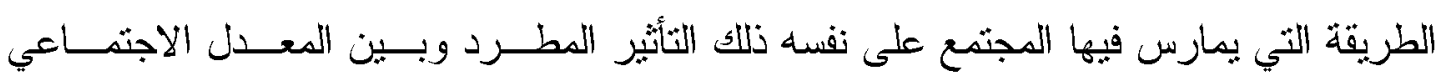

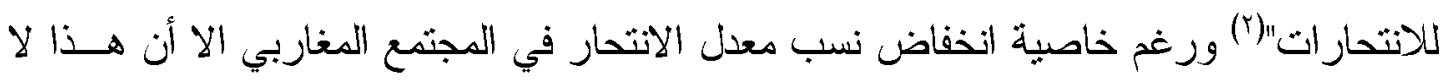

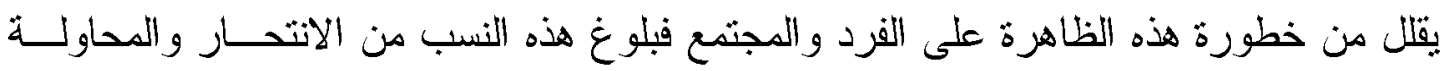

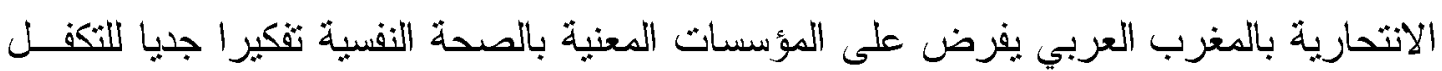

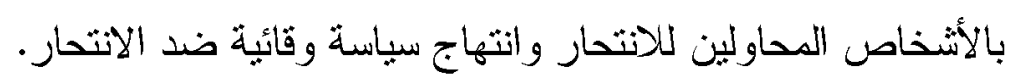

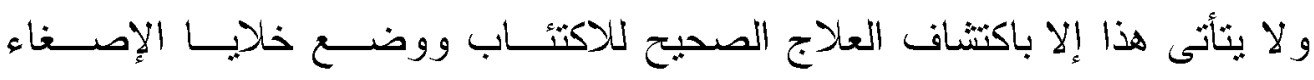

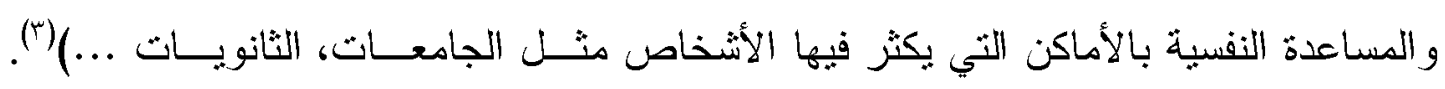

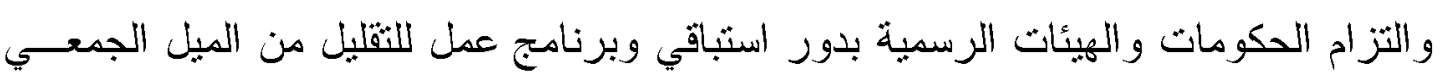

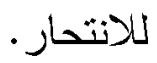

(1) Bensmail op.cit.p.992.

(3) Bensmail, la psychiatrie aujourd'hui, opu, Alger,1994,p,119-120 


\section{ه.انتشار الانتحار في الجزائر:}

إن ظاهرة الانتحار في تصاعد و انتشار مذهل منذ بداية العام .... r،فهي تأخذ أبعادا

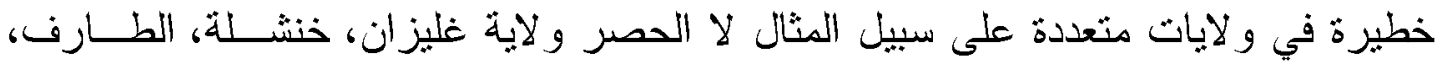

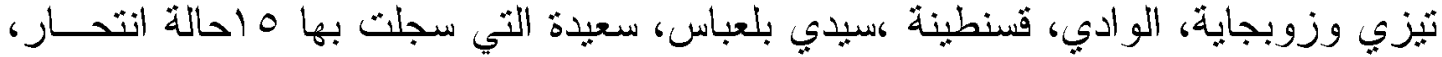

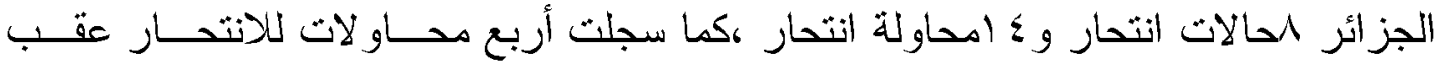

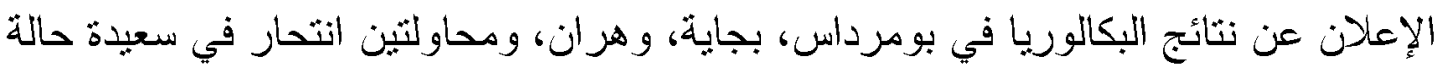
انتحار بو لاية بسكرة بوم زفافها (').

كما نتحدث وسائل الإعلام المكتوبة المنمثلة في الصحف اليومية دائما عن حـوادث الانتحار حيث نتشير الإحصائيات الصـادرة عن مصالح الدرك الوطني على مسنوى التـــراب

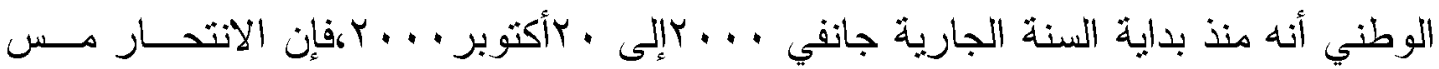

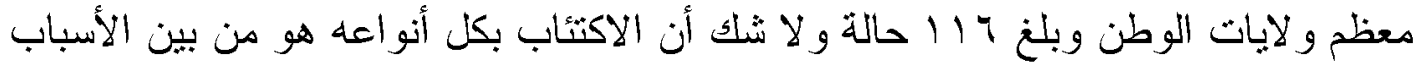

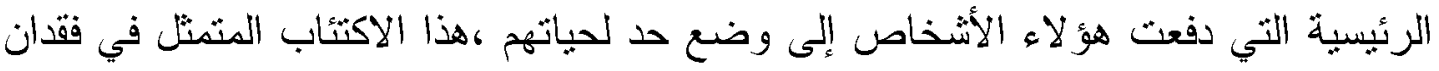

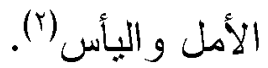
كما أنثار عدة باحثون جزائريون مثل بن خلفاة (979 (197)،بن سماعيل (9NV (1)،الذين اهتموا بظاهرة الانتحار في الجزائر أن التغير الذي شهده المجتمع الجزائري بعد الاســنقلال

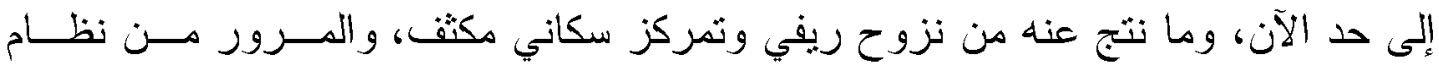

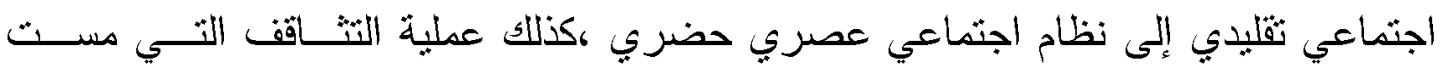

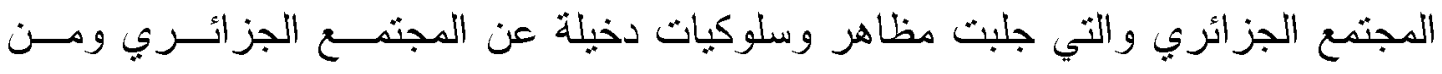

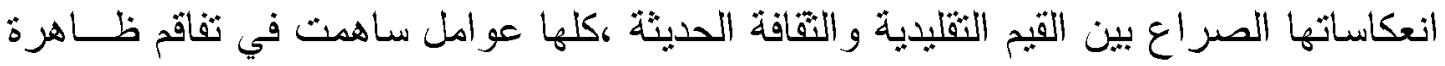
الانتحار والمحاولة الاتثحارية بالجزائر • وقام الدكتور بلخنتير بدراسة المحاولة الانتحارية

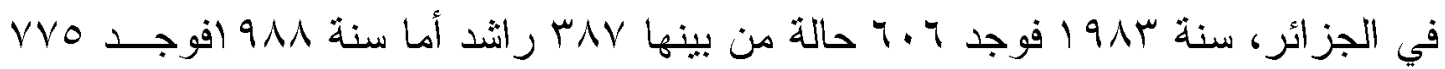

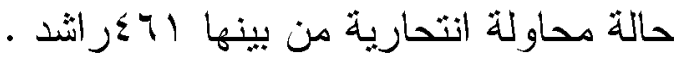

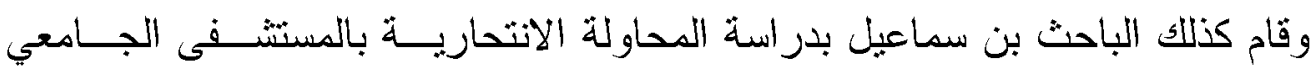

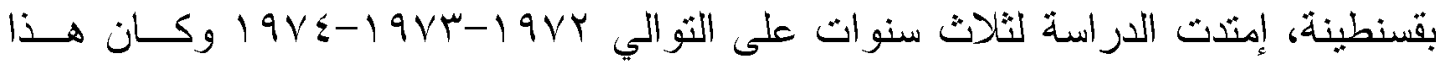
بمساهمة الباحث الصغير seghir، وشملت الدراسة كل المحاو لات الانتحارية الثي خضعت 
إلى فترة استثفائية في مصلحة الإنعاث ،كما قام بدراسة سنة 9AV اعلى المحاولة الانتحارية

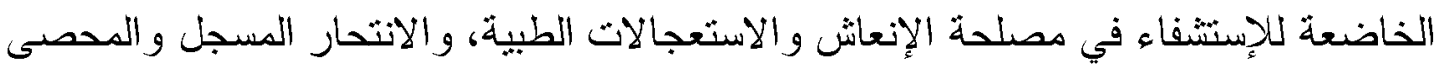

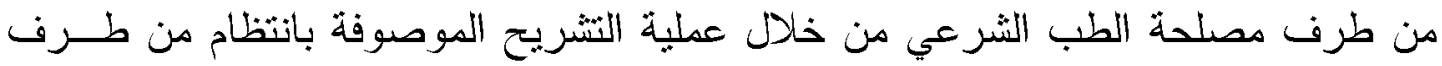
المصالح القضائية .

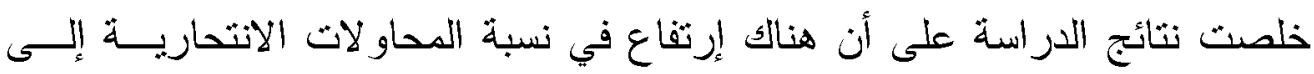

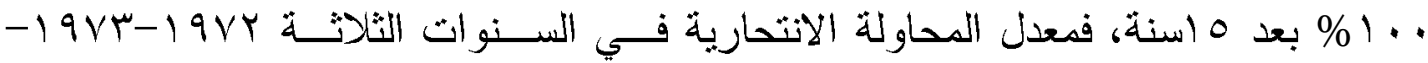

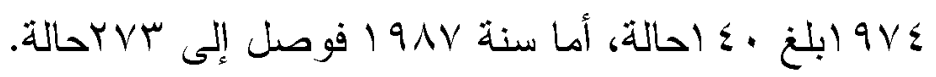
نسجل كذلك الاتنحار عام 9 الا يمثل إلا 0,0\% من كل السبر الانتحارية سواءا

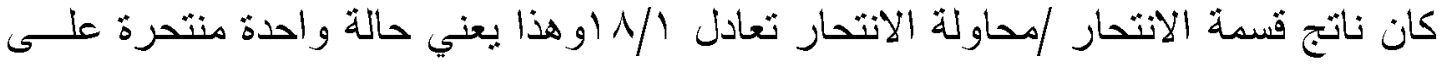

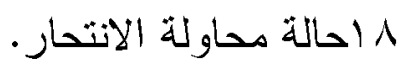

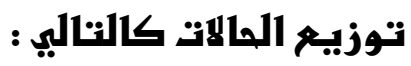

أ - أ - المحاولة الانتحاريتة:

× حسب الجنس: إن المحاولة الانتحارية نكون عند المرأة أكبر من الرجل بمرثين.

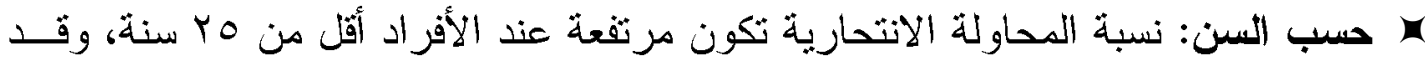

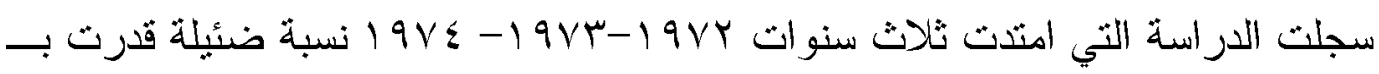

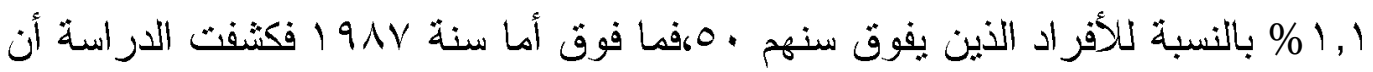

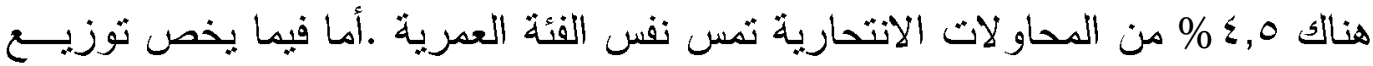

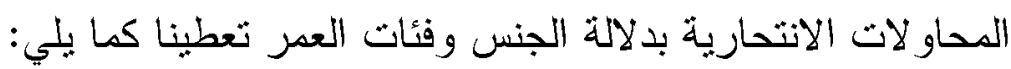

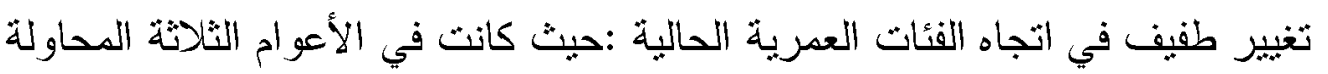

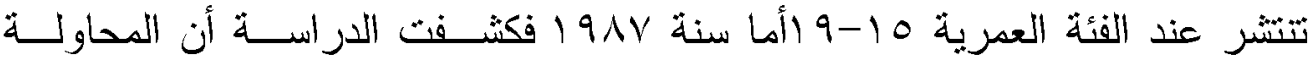
الانتحارية تنتشر عند الفئة العمرية . r-O كسنة .

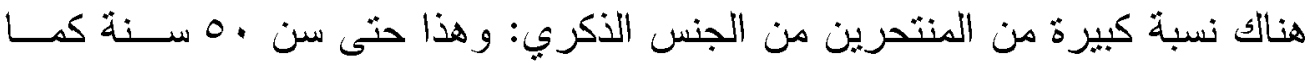

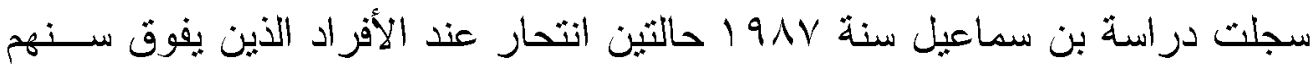

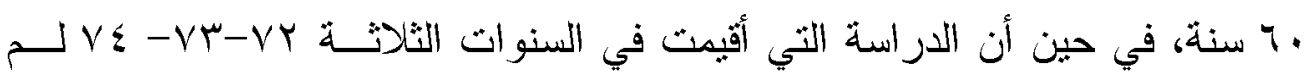
تسجل أبي محاولة تدخل ضينة فين ان هذه الفئة العمرية. كما سجلت الدراسة أن هناك انتشار للدحاولة الاتتحارية حسب الثهر ،فهناك ارتفاع نسبة المحاولة الانتحارية في شهر أفريل، مابي، وجوان، في شهر رمضار الشان. 


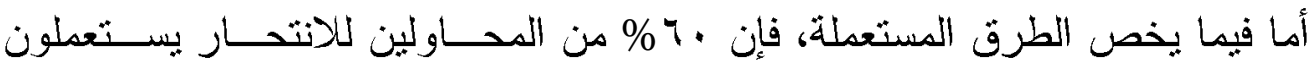

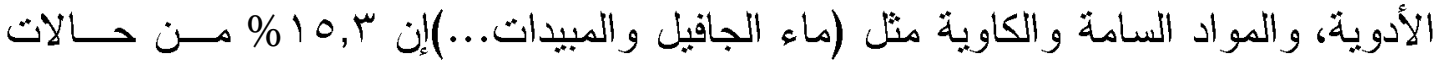

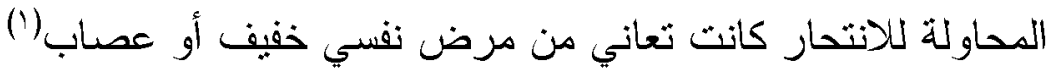

\section{ب - توزيع حالات الانتحار الناجحة :}

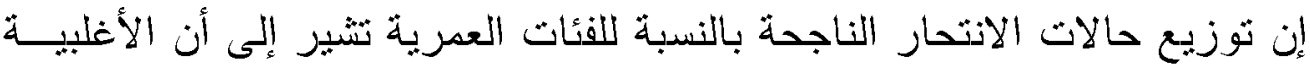

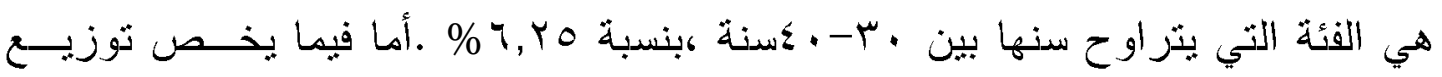
الانتحار حسب الجنس فنلاحظ إنعكاس في النسبة بالنسبة للدحاولة الانتحارية، فنســل

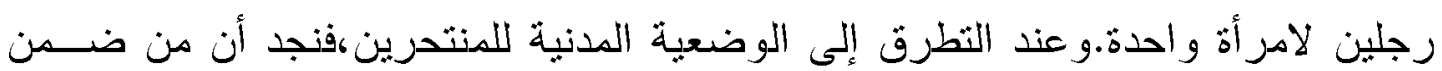

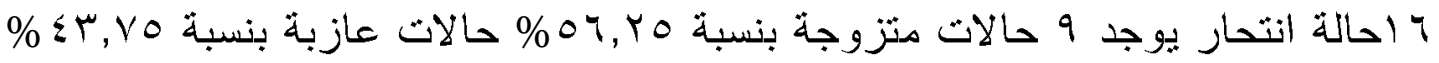

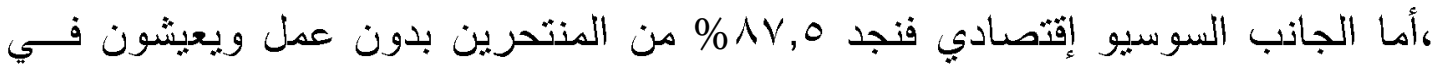
وضع اقتصادي منذفض جدا.

إن الأدوات المستعملة للانتحار ،0\% من المنتحرين فضلوا القفز من أعلى الجسور، الطريقة التي تغلب عند الجنس الذكرى أما البقية ففضلت الثنتق.

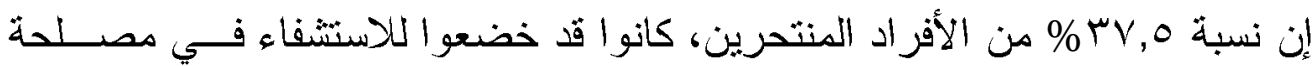

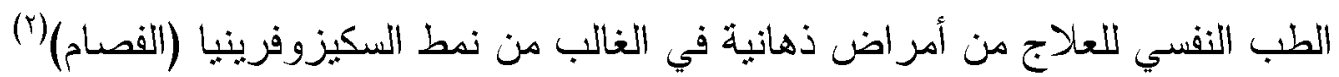

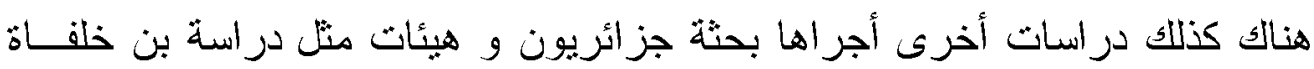

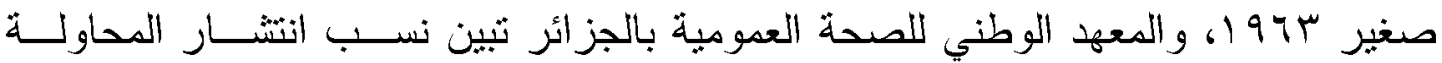

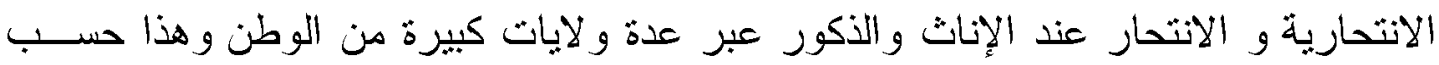

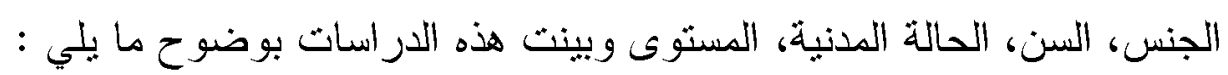

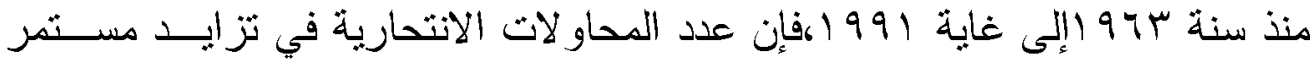

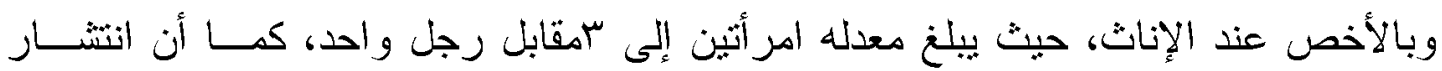

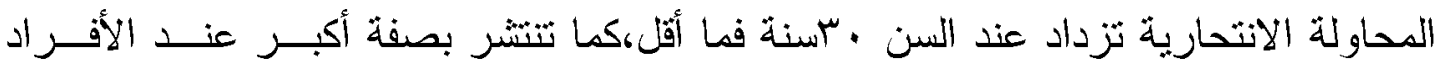

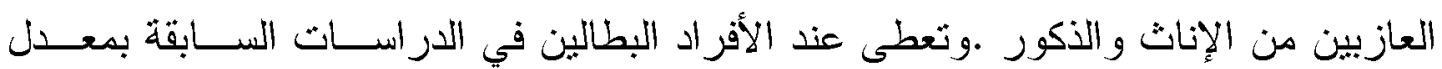

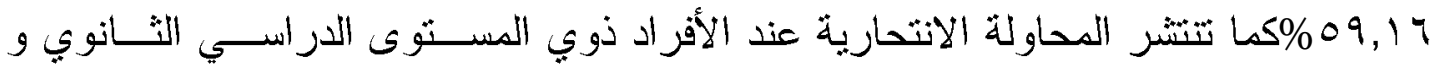

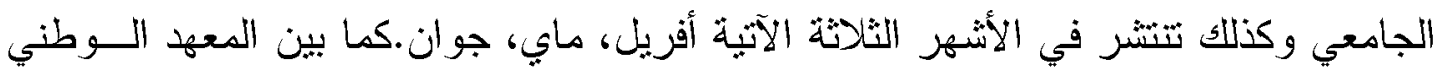

(1) Bensmail، suicides et conduites... ‘op.cit.p.994

(2) IBID. P.994.995

rTo 
للصحة العمومية بالجزائر في دراسته للمحاولة الانتحارية والانتحار أن السـلـوك المحــاول

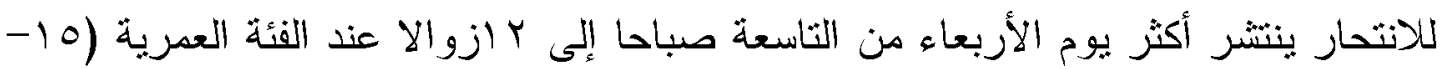

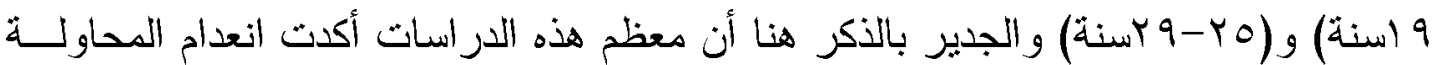

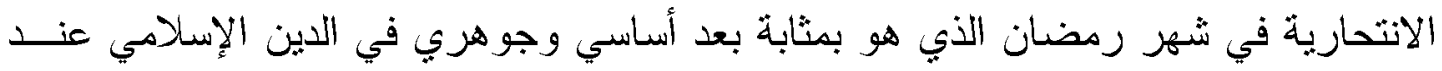

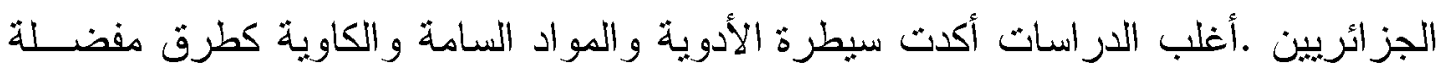

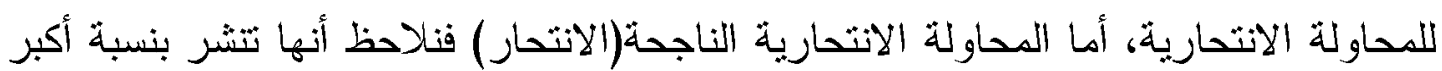

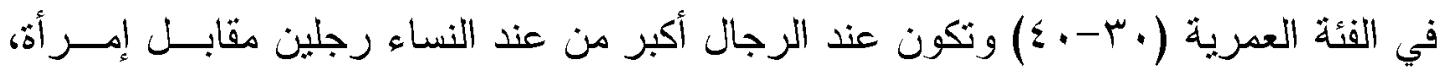

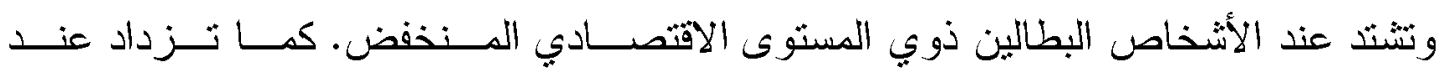
الأشخاص المثزوجين، وينفذ الانتحار بطرق متعددة حيث خلصت إليها دراسات بن سماعيل

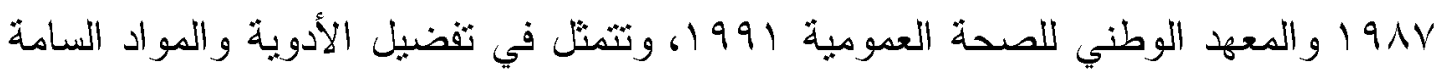

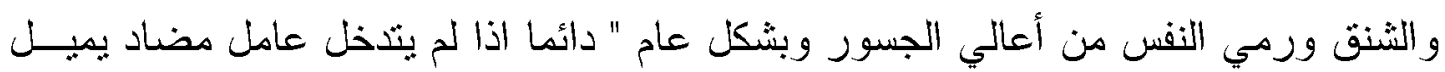

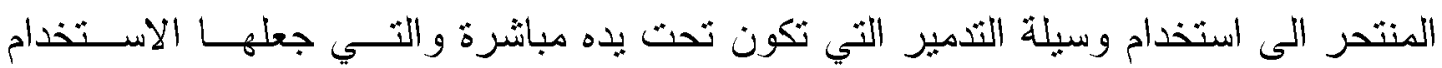

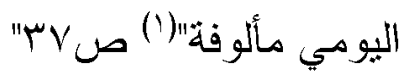

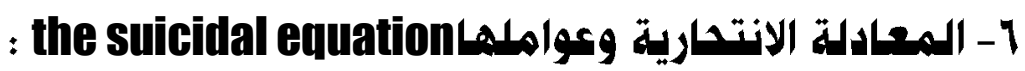

كما للمعادلة الرياضية أطر افها ،فإن للانتحار معادلته المنسبية فيه، فهناك العدبد من العوامل الني تحدد السلوك الانتحاري وتعمل على ظهورهوهيه النهي:

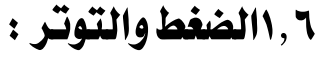

إن استمر ار الضغط بعمل على تكسير الاتزان الانفعالي لدى الفرد ويثيرفيه ســوك

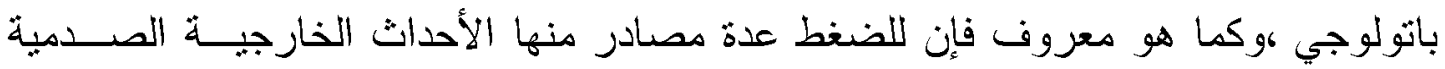

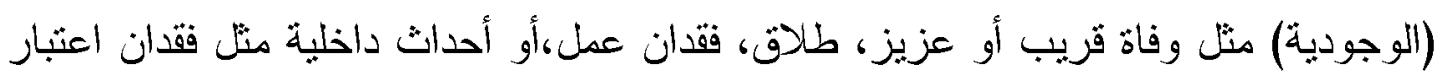

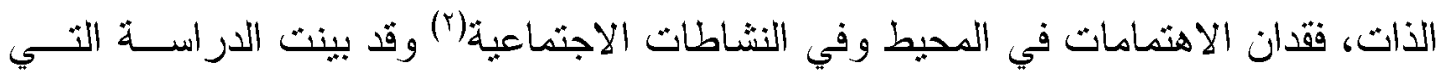

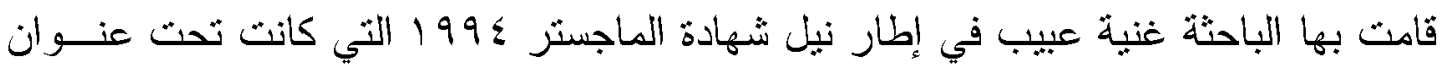

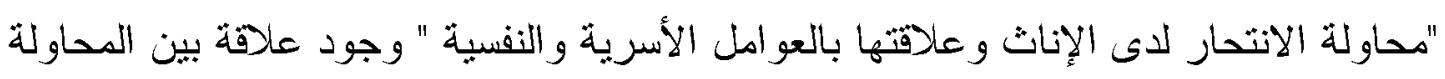

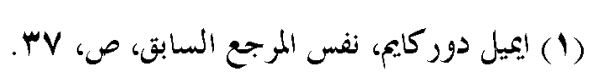

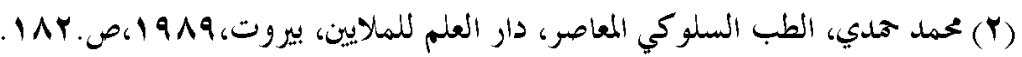


الانتحارية واضطراب المحيط الأسري، وكثرة النزاع والثجار بين الوالدين والأثر السـلبي للقسوة في معاملة الثابات (1).

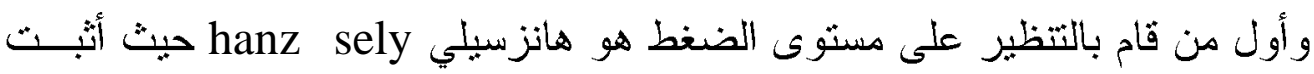

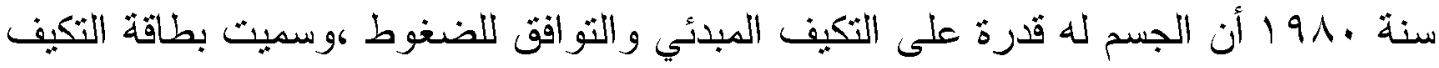

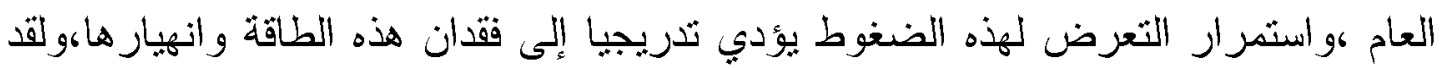

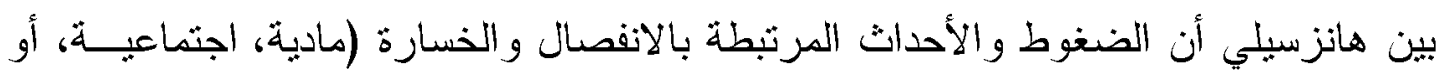

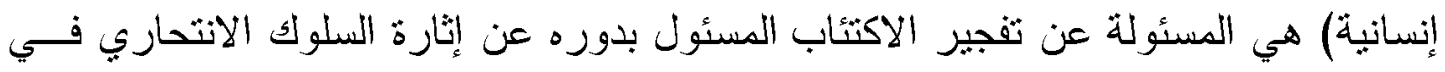

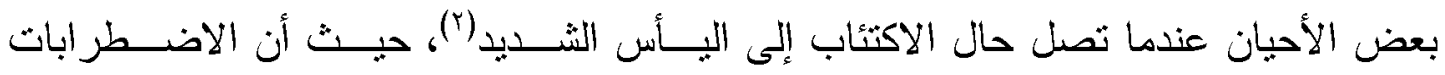

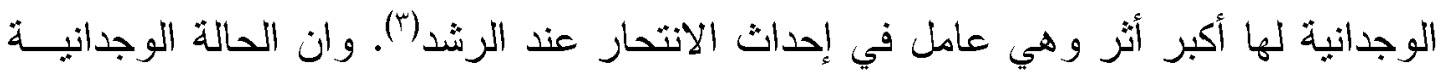

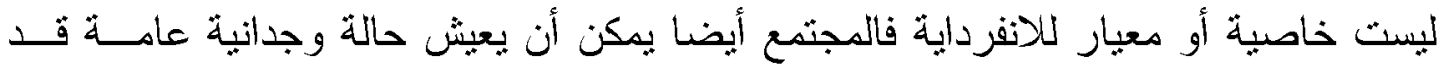

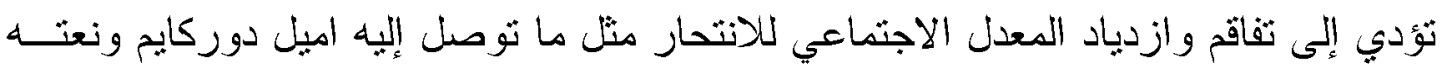

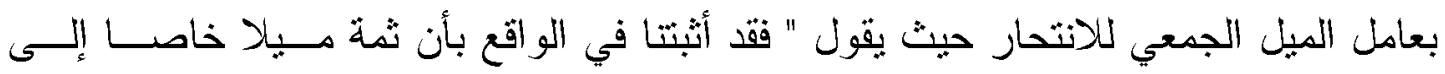

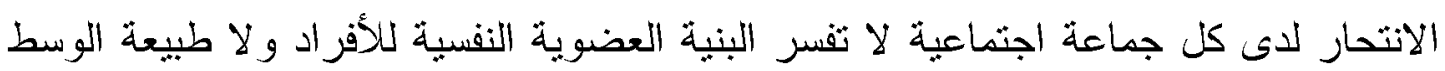

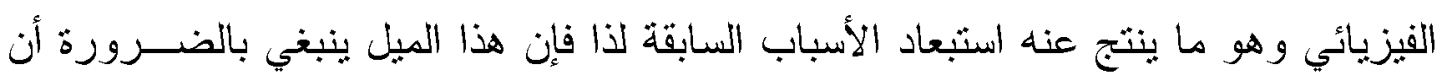

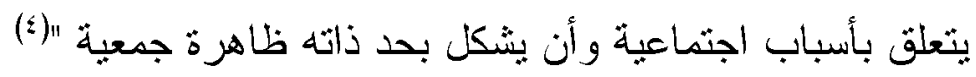

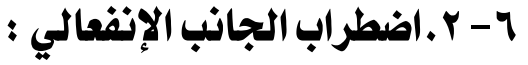

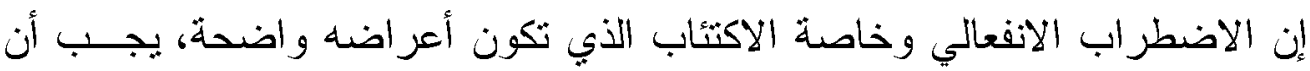

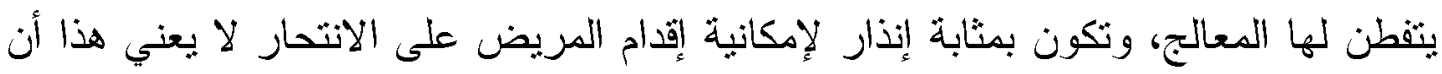

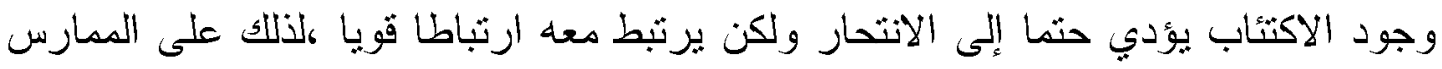

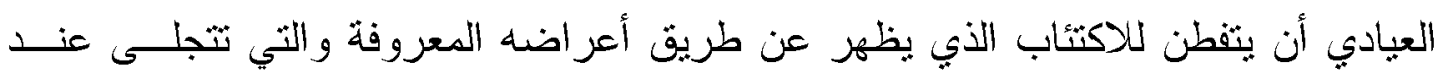

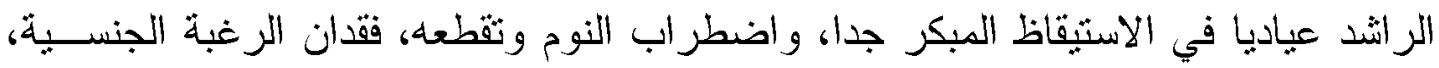

() (ا عبيب غنية، محاولة الانتحار لدى الإناث وعلاقتهما بالعو امل النفسية و الأسرية، رسالة ماجستير ، معهد علم النفس، جامعة

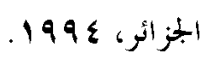

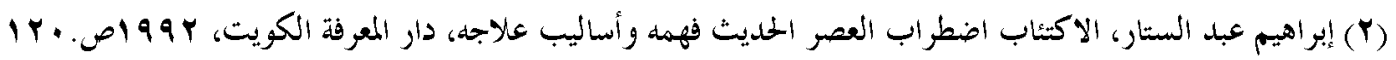

(3) Alan apter and al ، suicidal behavior ddépression and conduct disorders in hospitalized adolescents in academy Child psychol- adol n.6.1998.p.969 
نقص أو فقدان الثهية نحو الطعام، هذه الأعراض الفيزيولوجية هي انعكاس لطريقة الثخص المكتب في تقيبم المو اقف التي يتلقاها وتفسيره وتصوره لذاته، و عالمه ومستقبله، وطبعا كما أوضحنا هذه الطريقة التفسيرية نكون تحمل اعثقادات خاطئة لاعقلانبة تؤدي إلى إبــثرار

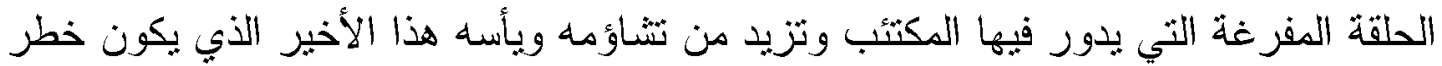

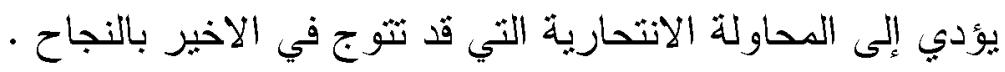

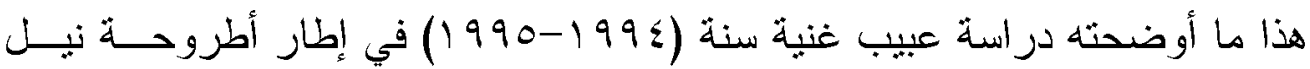
شهادة ماجستير أن الثابات المحاو لات للإنتحار يتميزن ببعض الخصائص الثخصية التـي

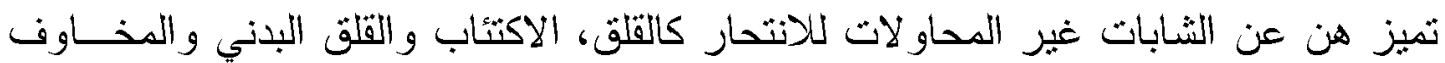

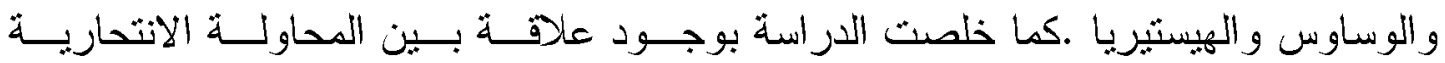
والاضطر اب النفسي المتمثل في الاكتئاب، هذا ما خلصت إليه كذلك دراسة يحباوي 1997 في نفس الإطار ، لنيل شهادة الماجستير إلى وجود علاقة وطيدة بين فقدان الأمسل (البــأس)

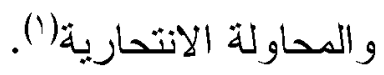

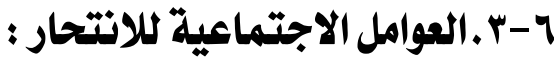

يشير اميل دوركايم Emile Durkheim من خلال الدراسة السوسيولوجية المعدةـــة

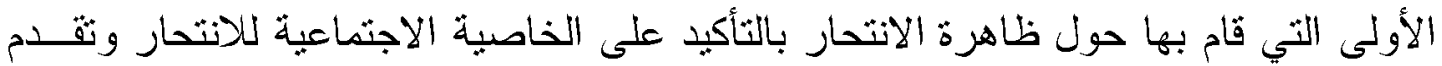

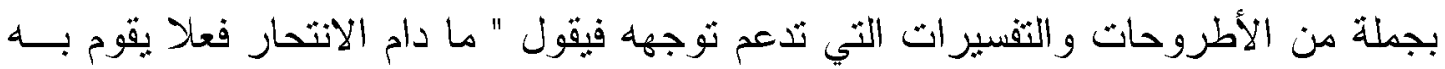

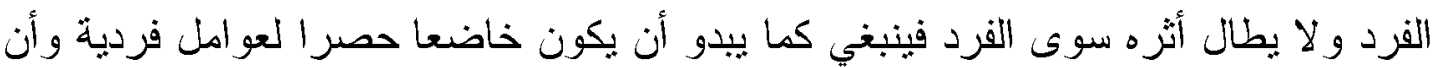

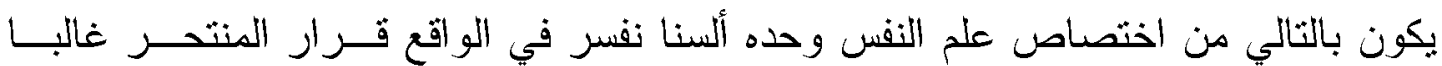

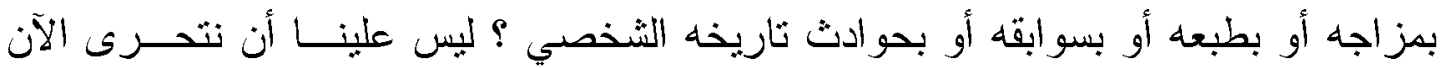

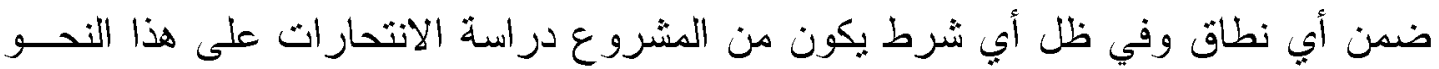
ولكن من المؤكد أنه من المدكن النظر الى الانتحارات من جانب آخر مختلف تماها و الواقع

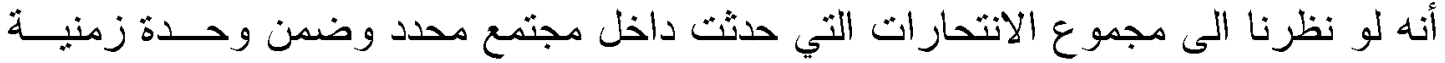
محددة بدلا من النظر البها كحوادث خاصة معزولة بعضها عن بعض بحيث بحتاج كل منها

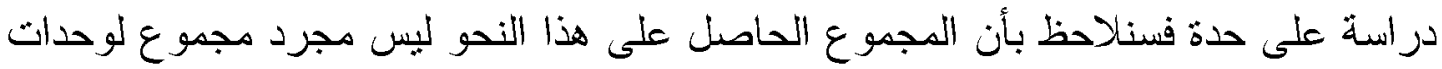

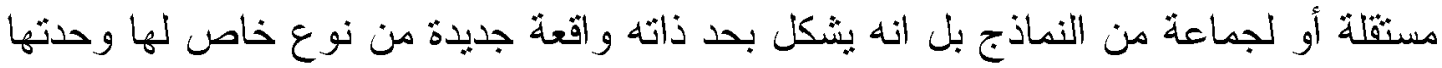




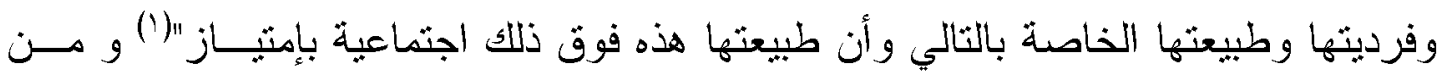

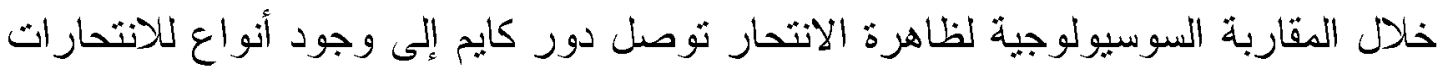

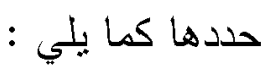

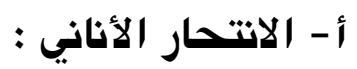

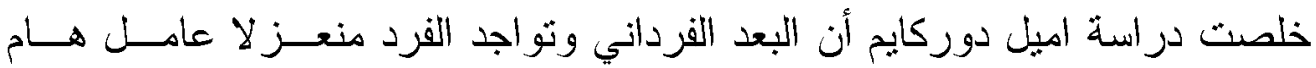

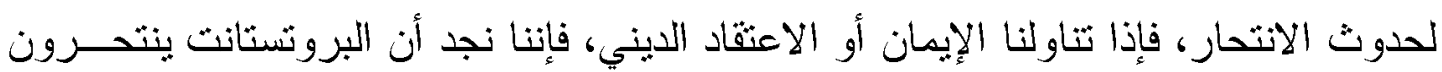

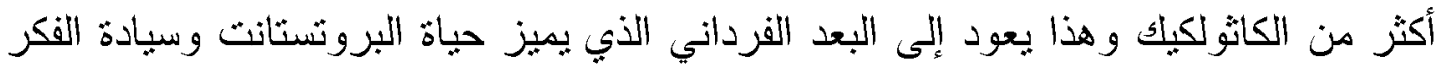

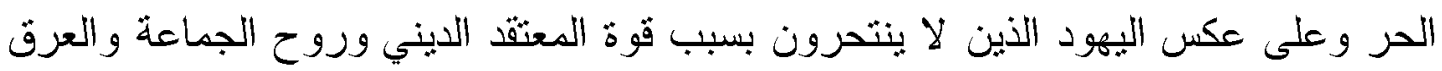

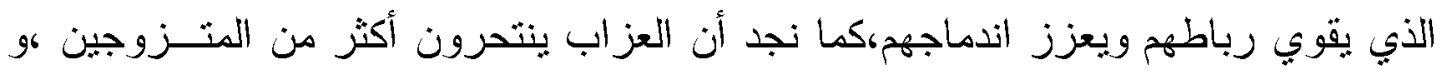

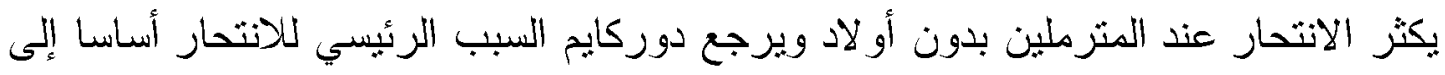

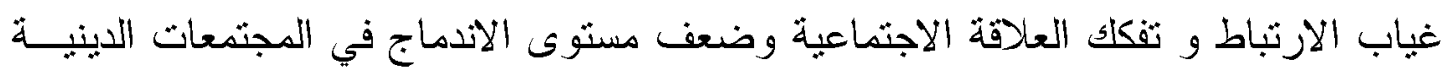

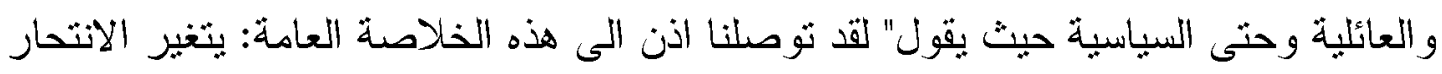

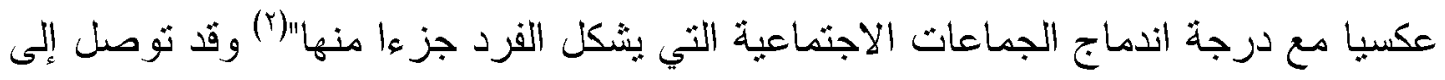

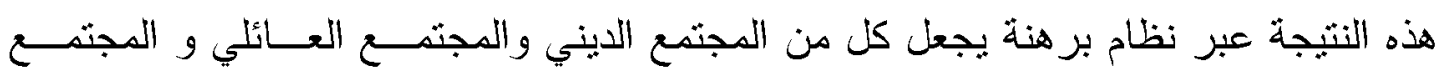

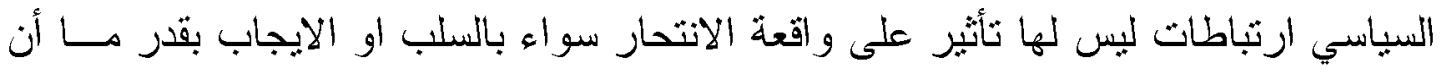

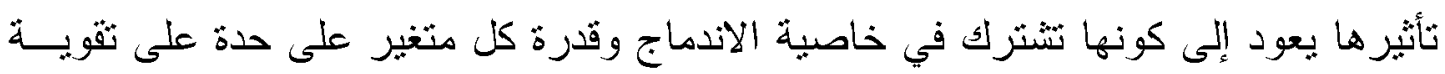

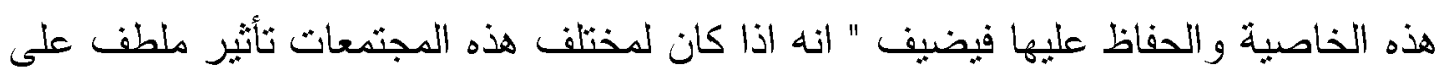

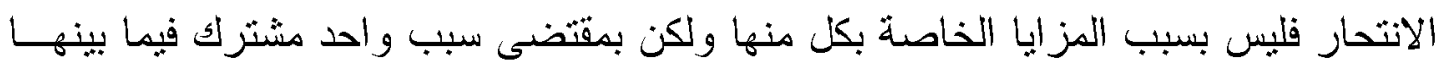

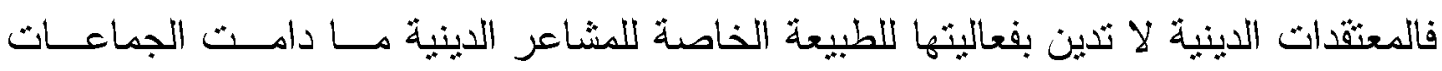

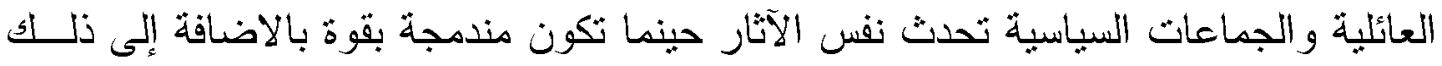

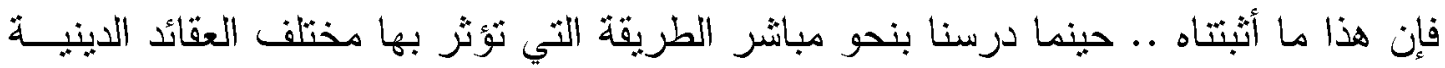

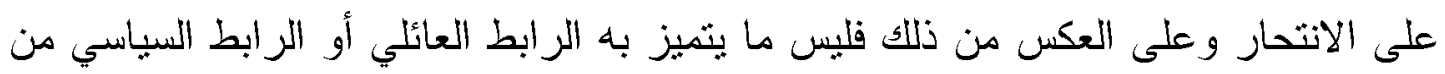

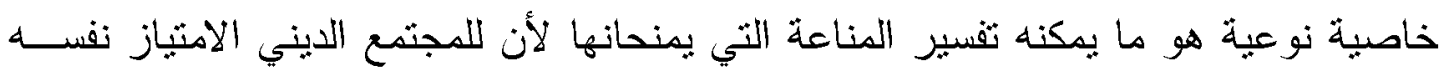

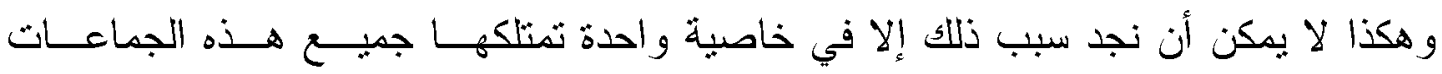

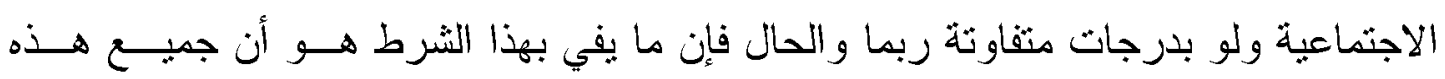

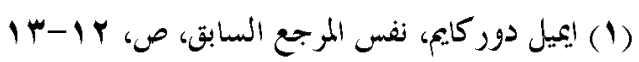

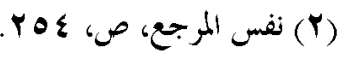


الجماعات الاجتماعية مندمجة بقوة"(1) و اذا انفصم هذا الرباط و تخلخلت مو ازين الانــدماج

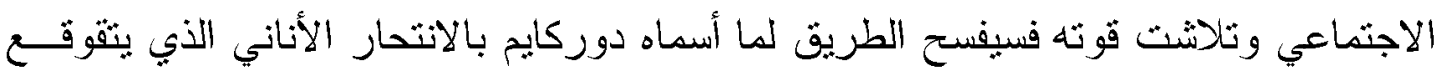

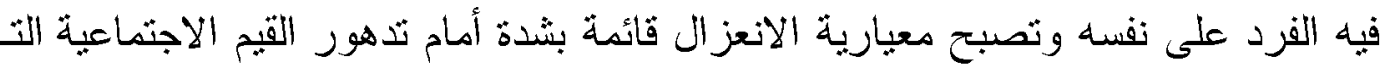

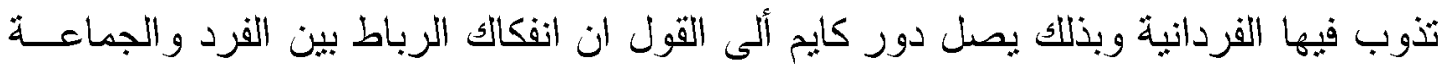
هو المحد للانتحار الاناني فيصف قائلا " ان الجماعة الاجنماعية لا يمكن أن تثنكك من دون

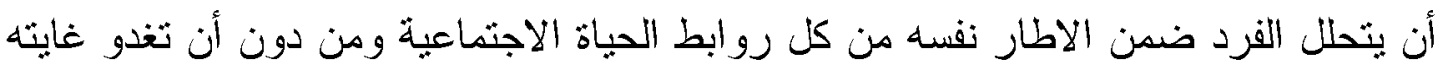

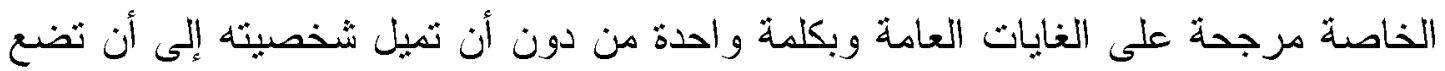

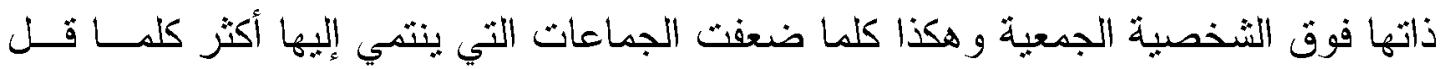

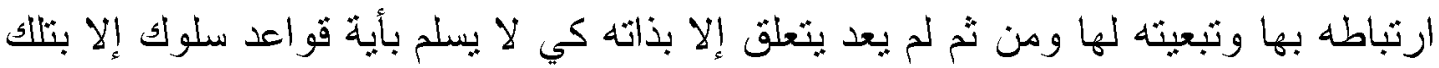

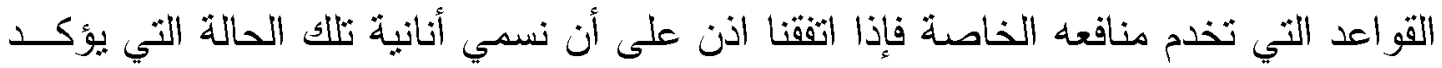

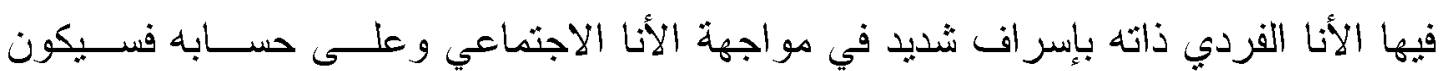

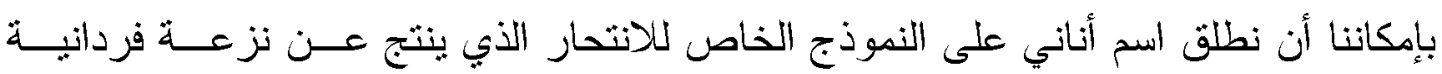

مفرطة")(r)

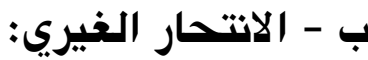

وينتشر ضمن المتثعات البدائية والاينية شديدة التماسك بل و المفرطة فيه، "وهكــا

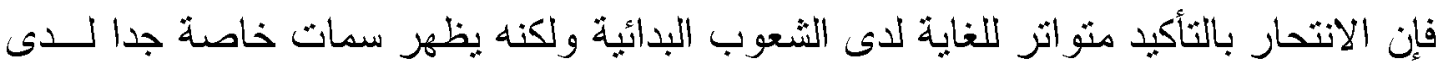

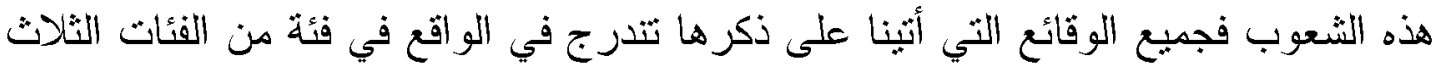

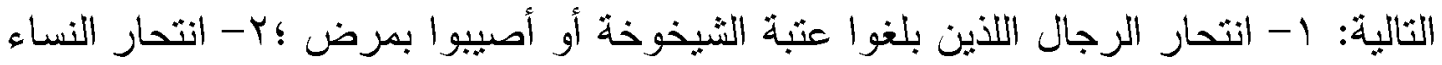

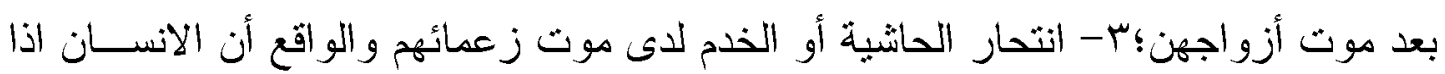

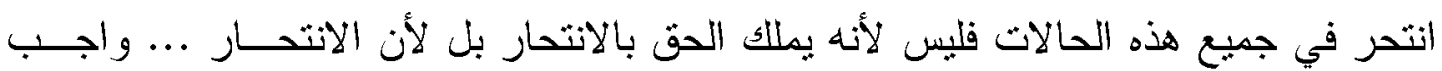

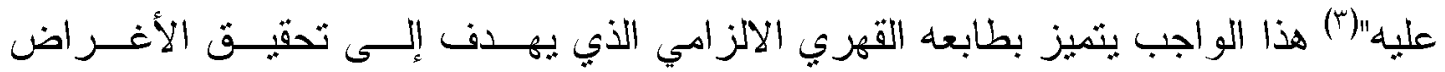

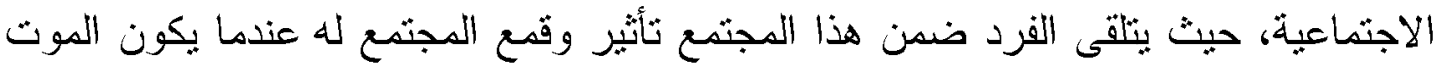

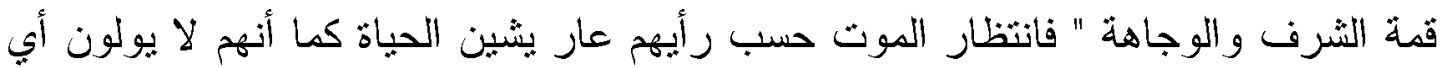

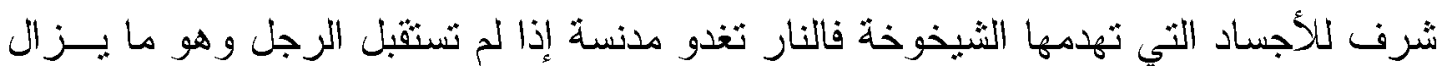


حبا"(') كما أنه من قمة الوفاء أن تتنحر النساء المترملات عقب أزواجهن وهذه الطقوس ما

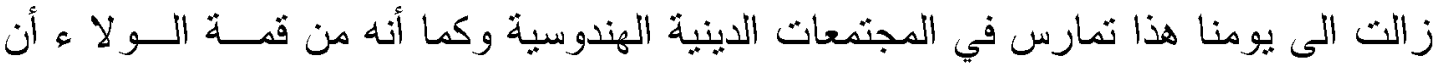

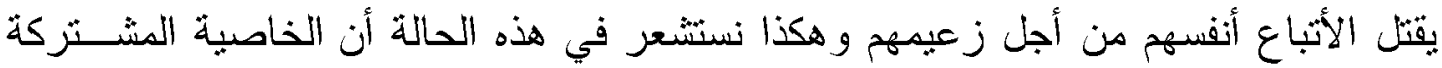

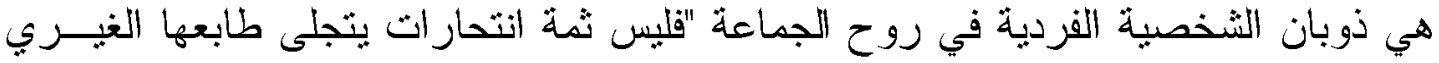

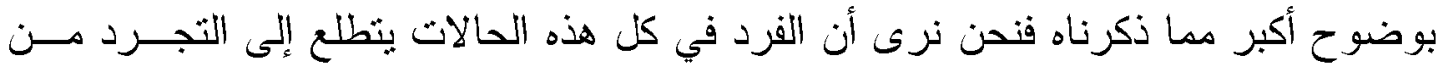

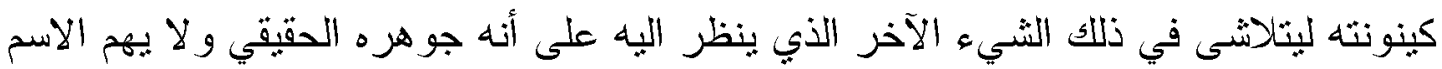

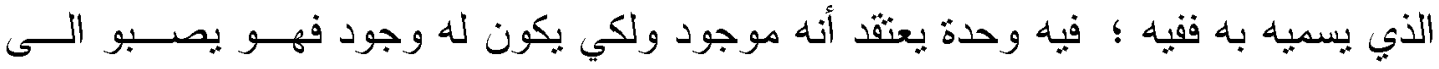

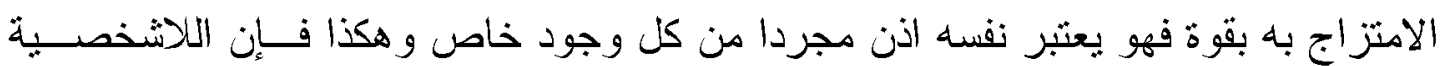

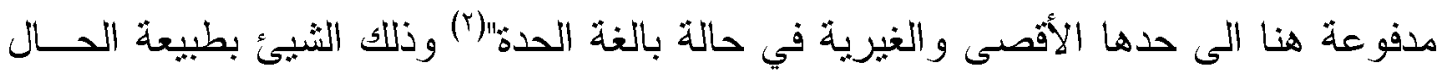

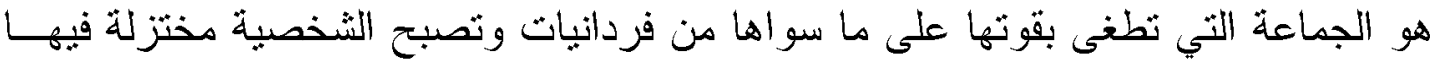

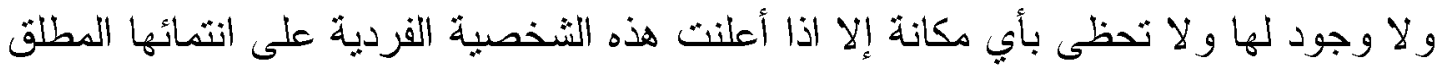

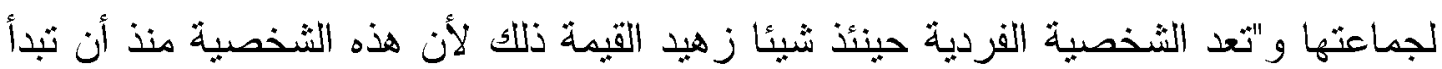

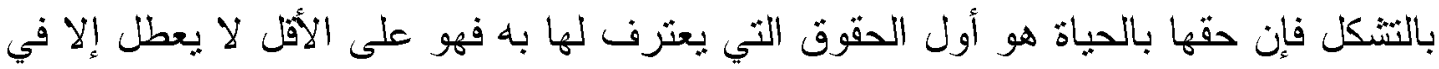

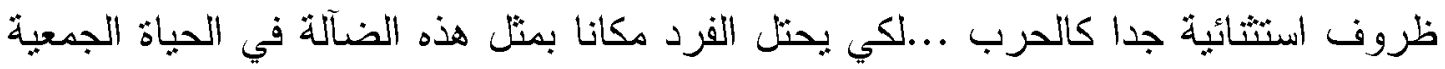

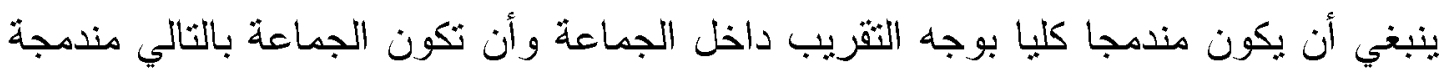

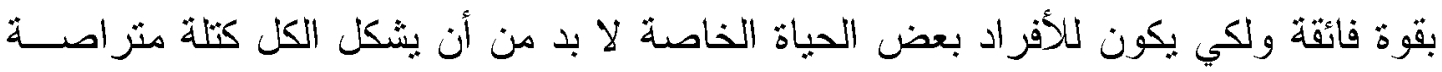

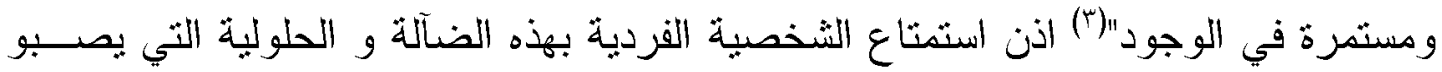

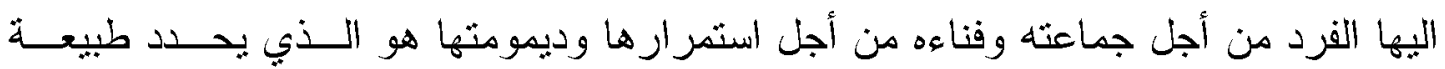

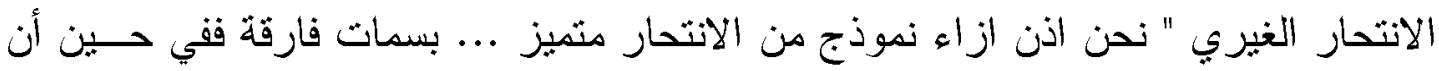

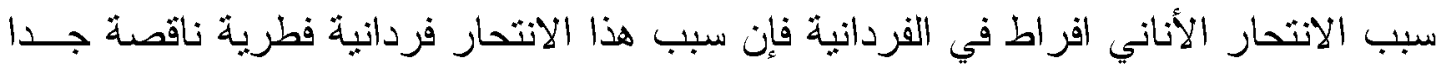

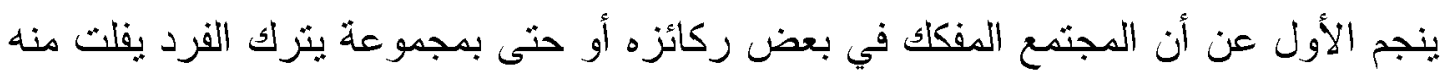

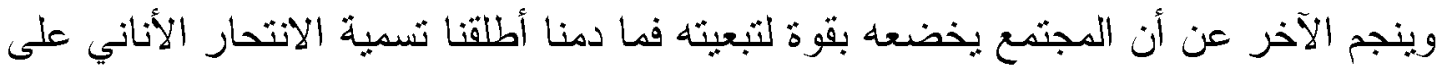

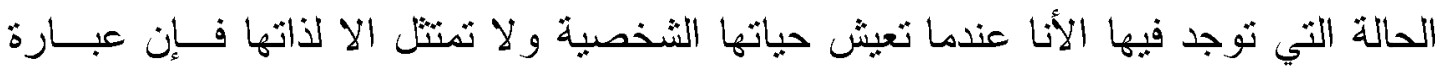

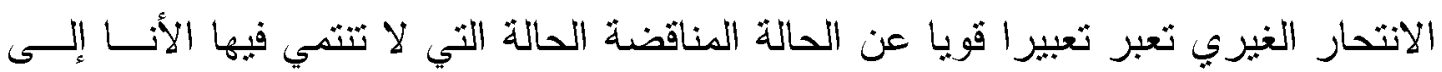

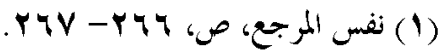

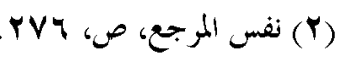

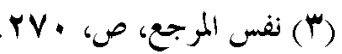


ذاتها بل نمثزج بثنئ آخر غير ذاتها حيث يقع قطب سلوكها خارج ذاتها أبي داخل جماعــة من الجماعات تعد جزءا منها لهذا سنسمي انتحار| غيريا ذلك الانتحار الذي ينجم عن غيرية

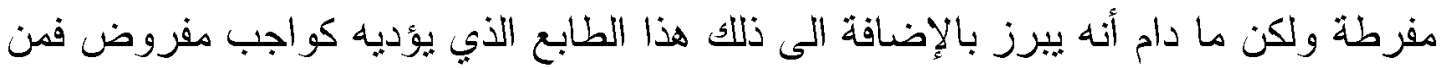

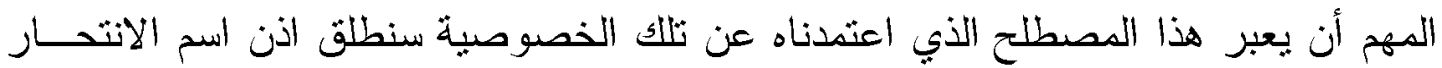

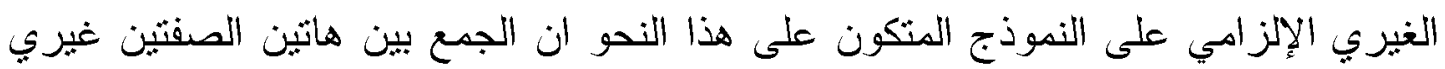

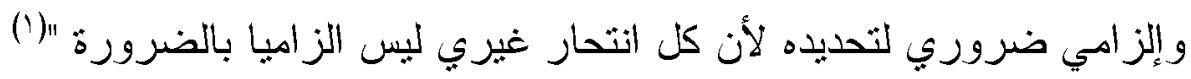

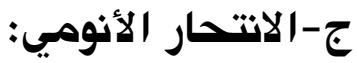

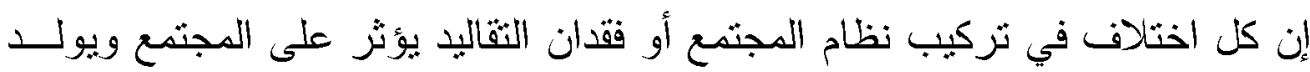

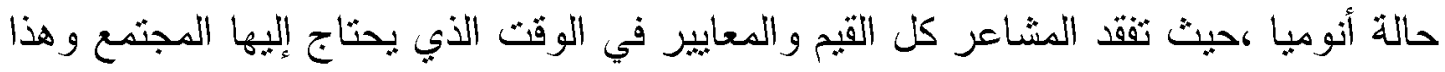

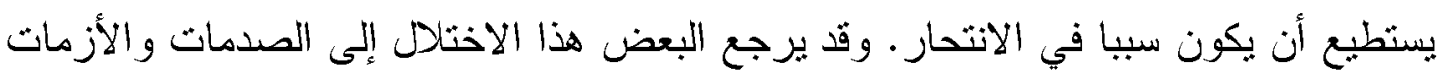

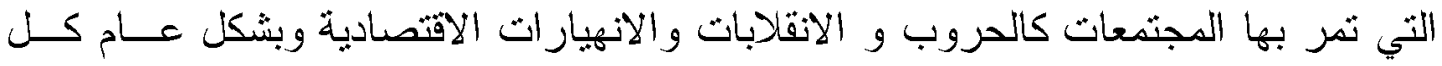

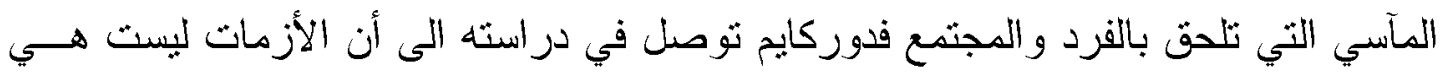

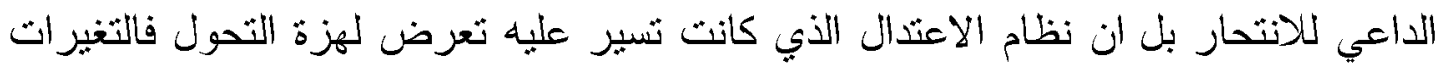

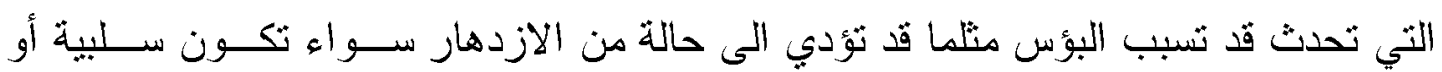

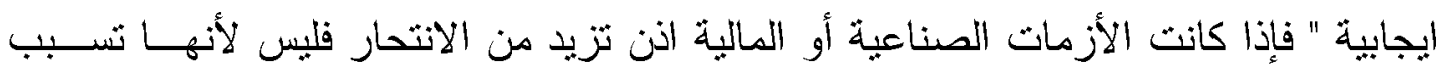

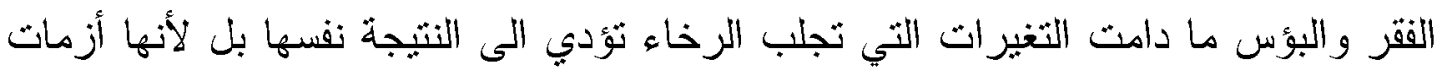

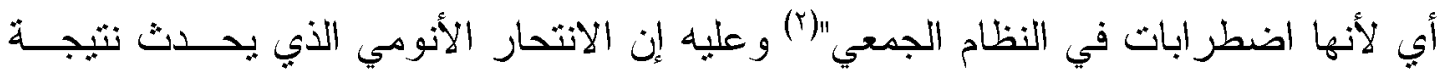

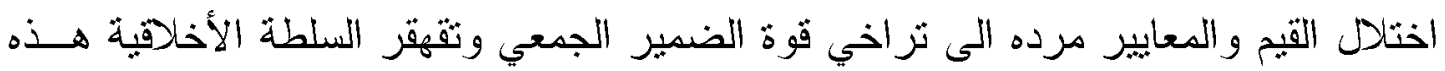

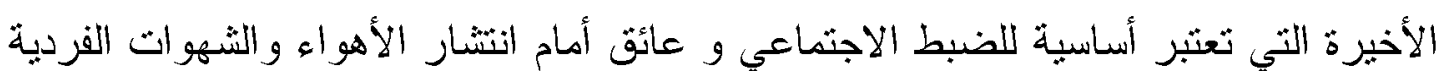

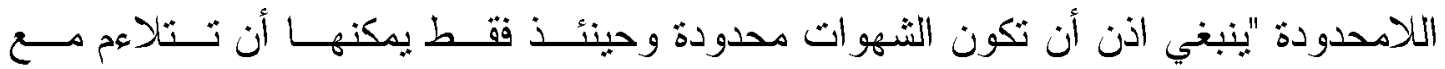

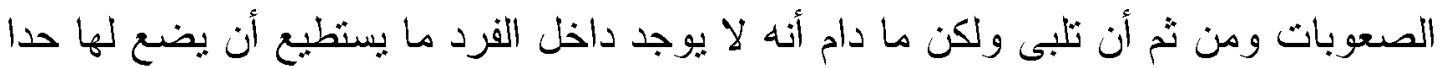

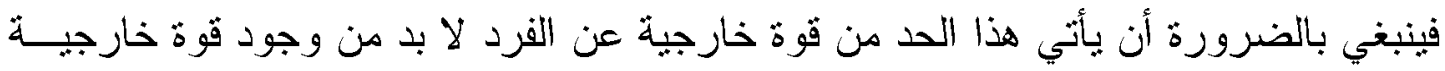

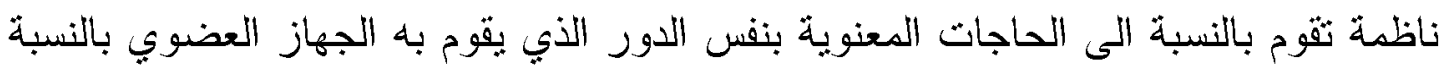

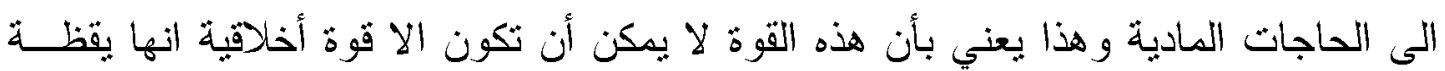
الضمير الثي تثنل لكسر حالة النوازن التي يهجع داخلها الحيوان فالضمير وحده اذن مسن النّن

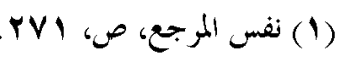

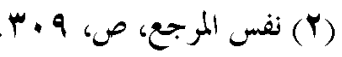




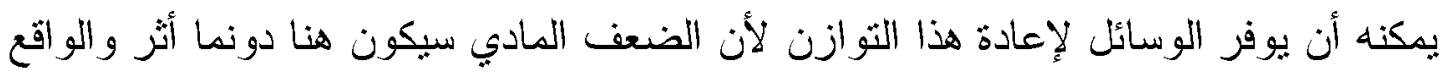

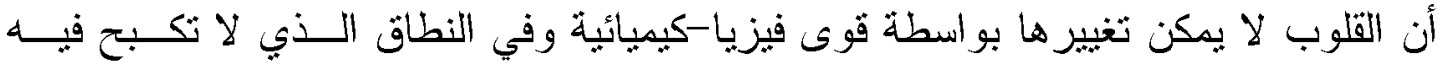

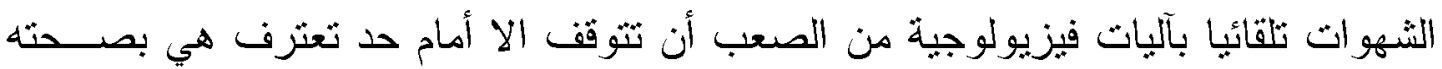

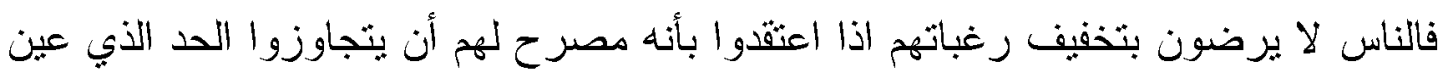

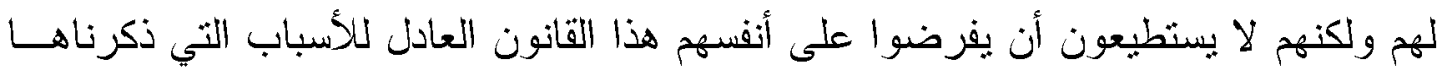

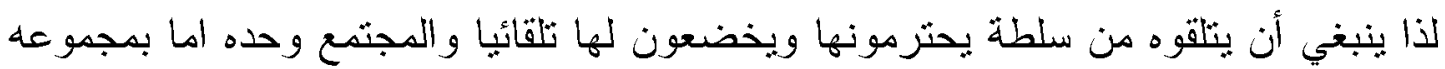

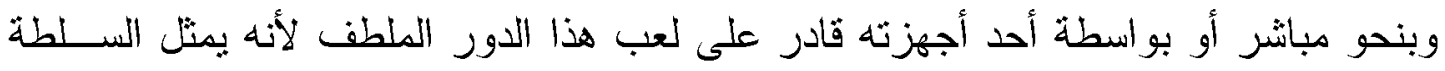

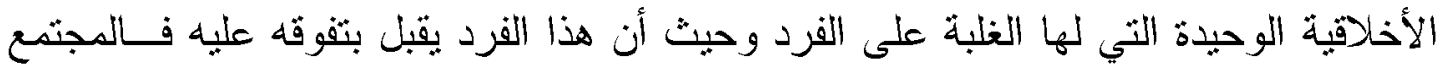

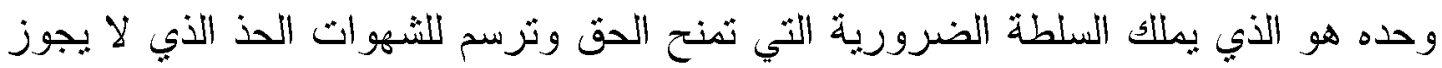

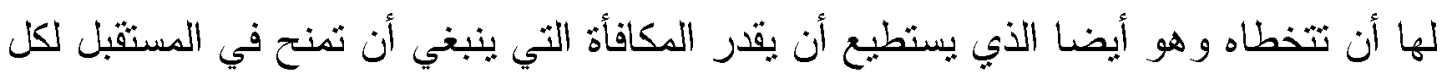

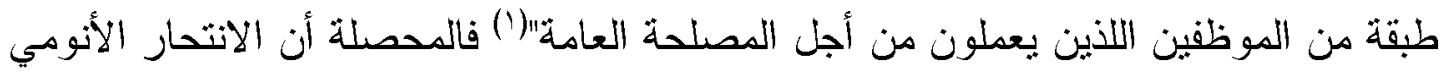

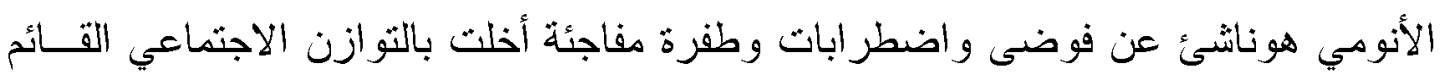

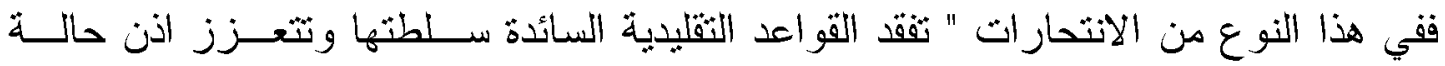

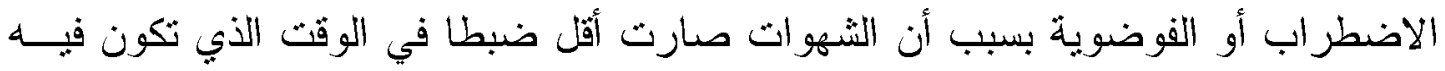

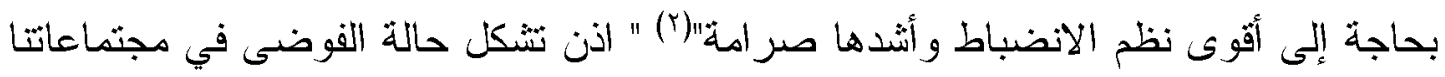

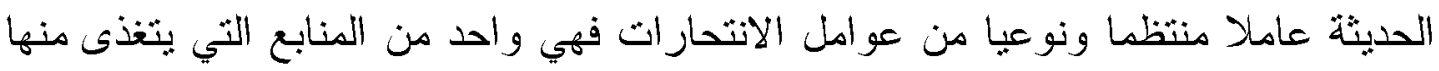

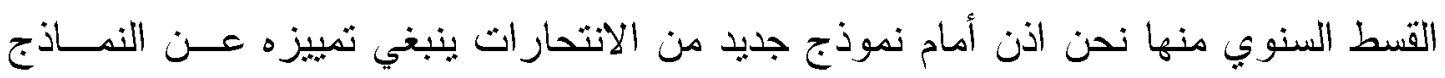

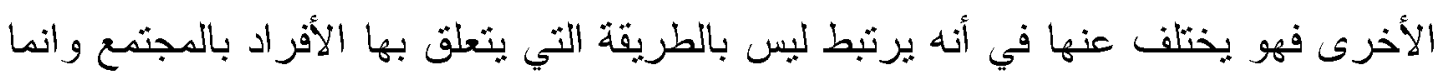

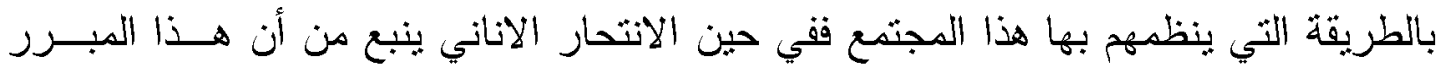

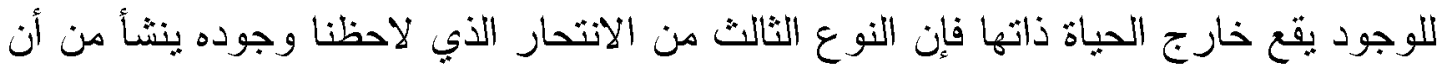

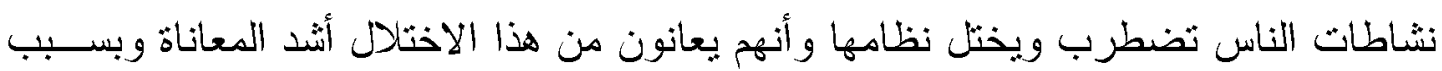

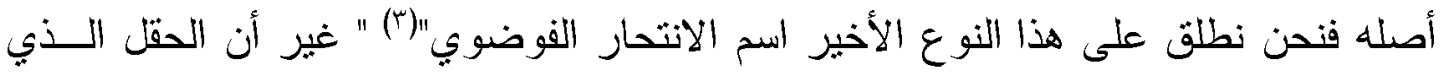

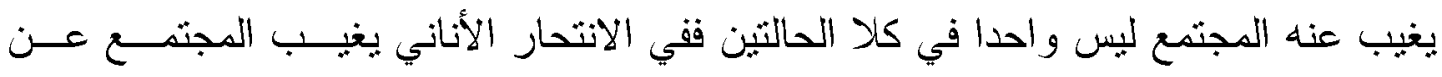
النشاط الجمعي حصر ا تاركا اياه مجردا على هذا النحو من الهدف ومن المعنى وفي الانتدار

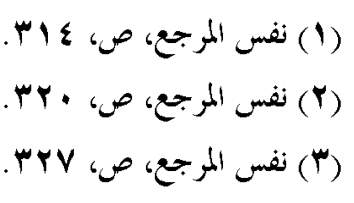


الفوضوي بغيب المجتمع عن الأهو اء الفردية الجامحة حصر انتاركا اباها على هـذا النحسو دونما ضابط يضبطها" (1)

حسب هذه الأنواع الثلاثة للانتحار نسنطيع أن نقول أن هنــاك أســباب إجنماعبــة

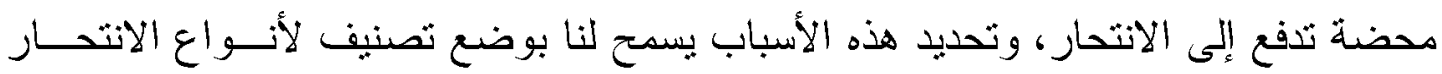

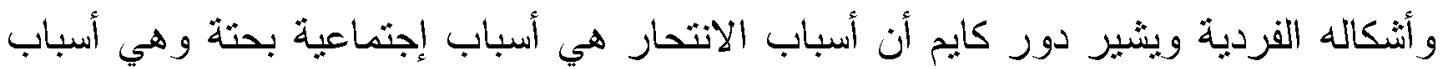

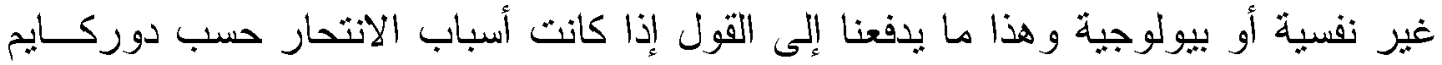

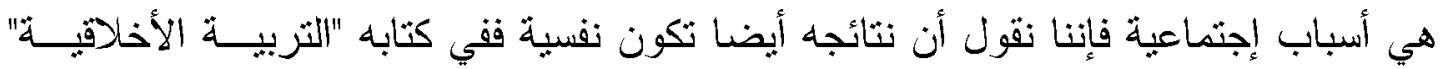

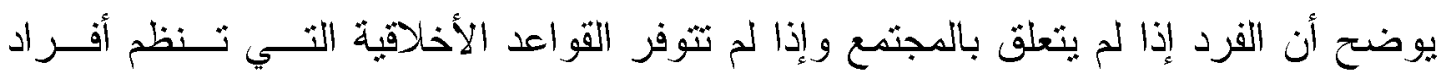

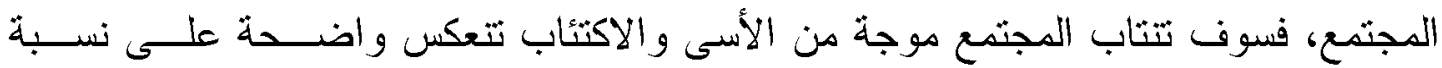

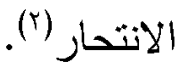

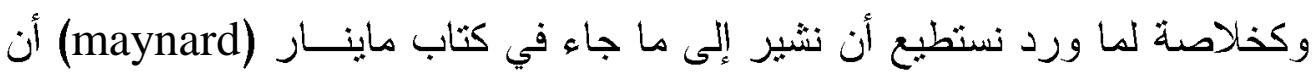

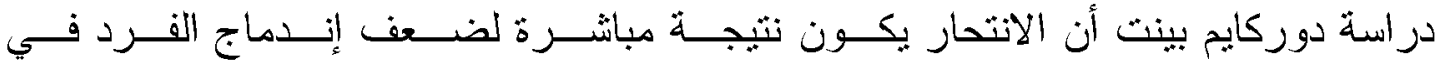

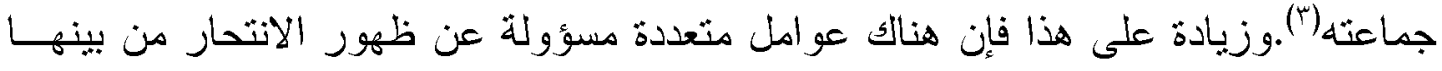

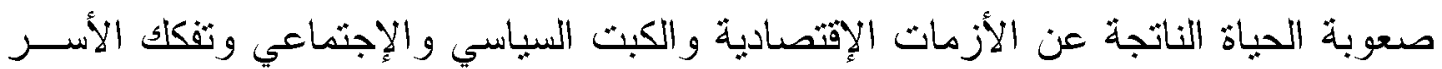
وضعف الوازع الديني (\&).

و هذا مأكده رئيس الحكومة الجزائري السابق أحمد بن بيتور فــي مداخلاتـــه أمسام

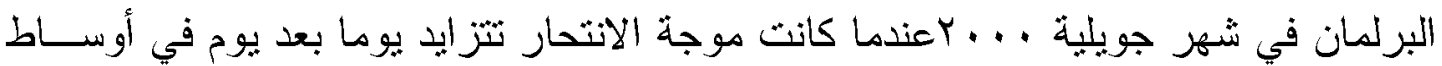

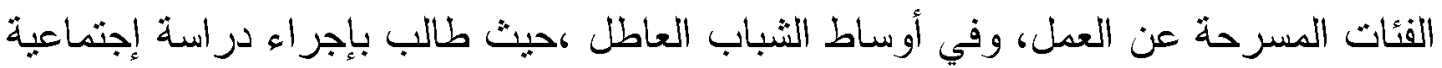

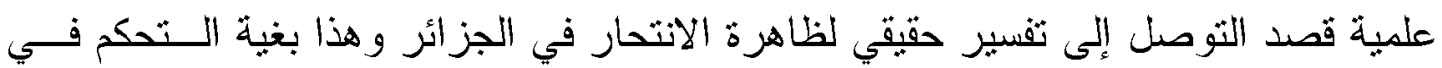

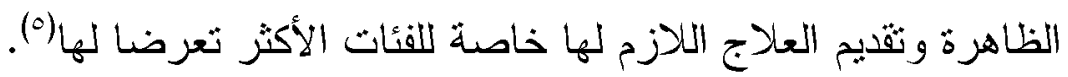

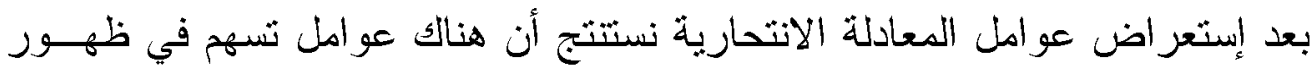

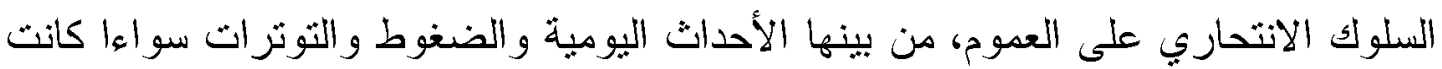

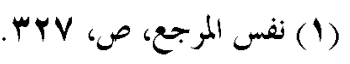

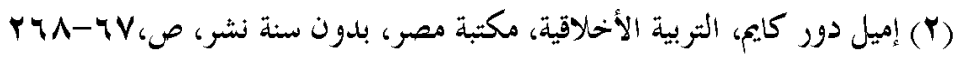

(3) Maynard. 1 ،le suicide ،étude normale et métaphysique ،puf. paris.1985.p.12

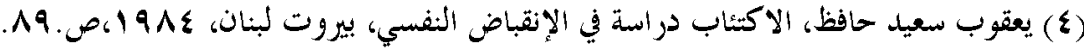

(5) AÏT OUFELIA Mourad, «Benbitour interpellé sur les suicides », in Liberté, $\mathrm{n}^{\circ} 2367,24$ juillet 2000 . 
داخلية نفسية كفقدان إعتبار الذات ،ققدان الثقة بالذات أو خارجيــة مثــل خســارة مركـز

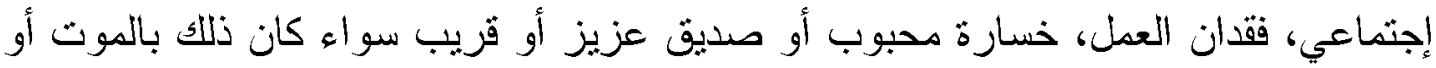

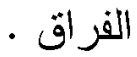

كما أن الاضطر ابات النفسية تساعد على ظهــور السـلـوك الانتحـــاري و العوامـلـل

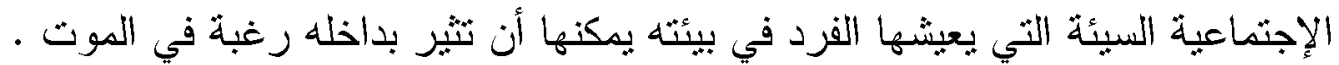

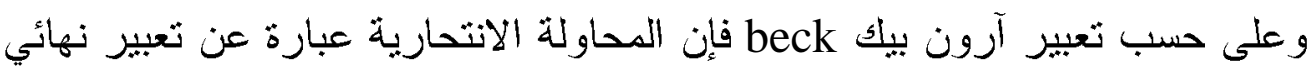

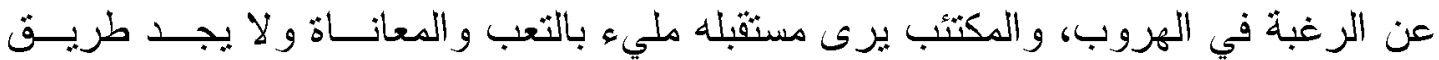

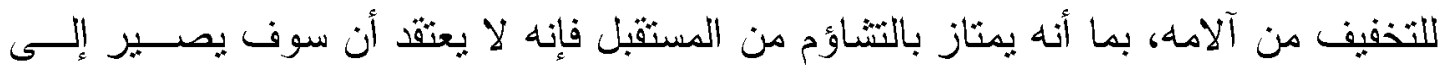

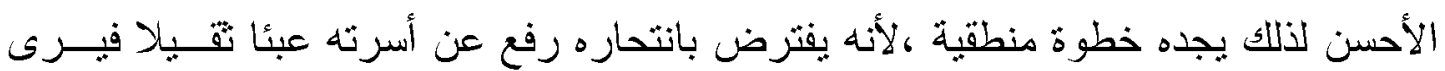

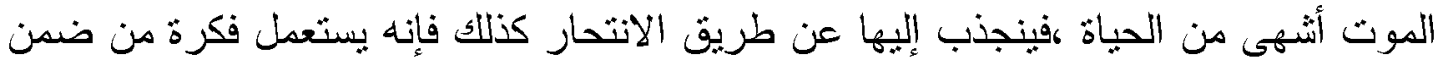

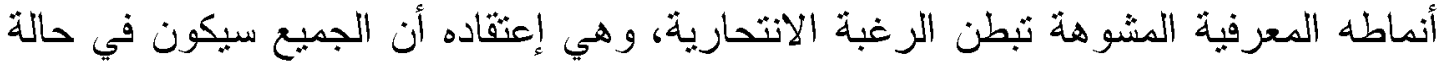

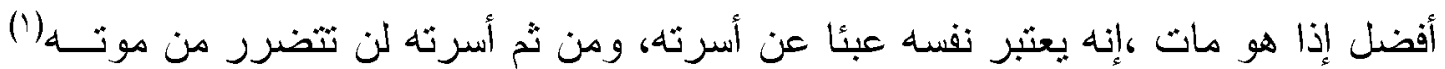

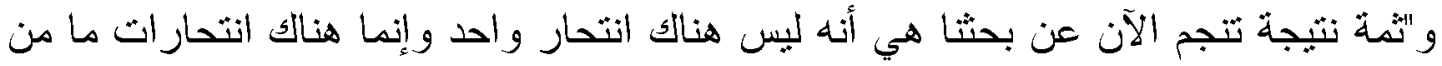
شكك بأن الانتحار هو على الدوام فعل يقوم به انسان يفضل الموت على الحباة ولكن الأسباب

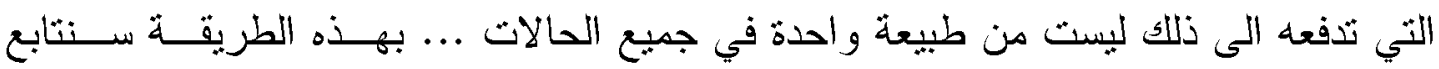

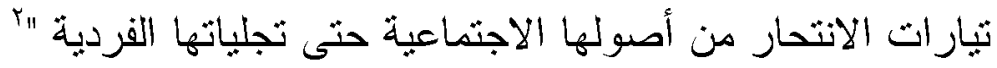

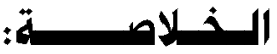

لا شُك أن الاحصائيات و الدراسات التي نتاولت الإنتحار جعلت مـن هـــا الفعـل

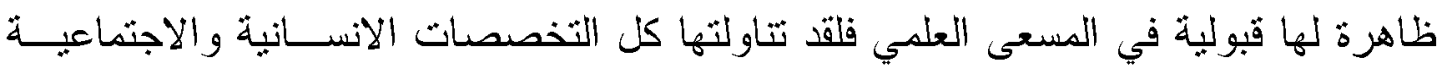

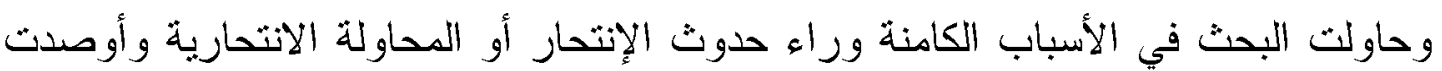

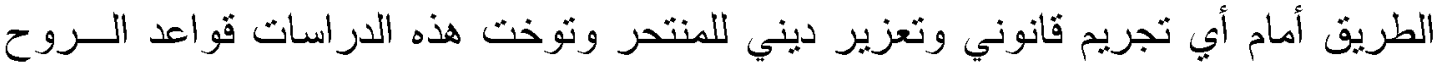

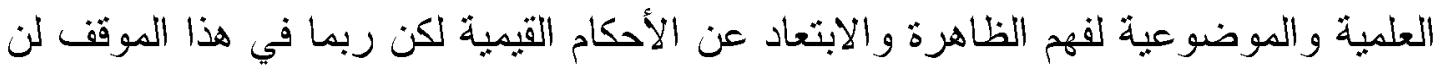

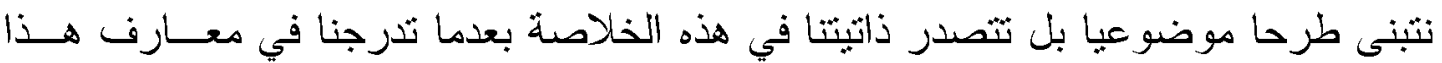

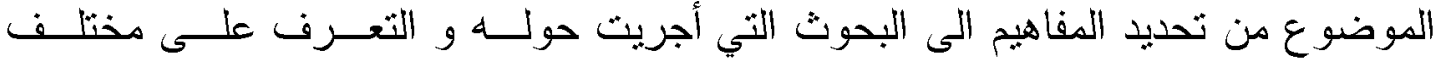

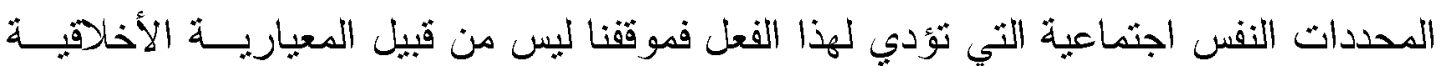




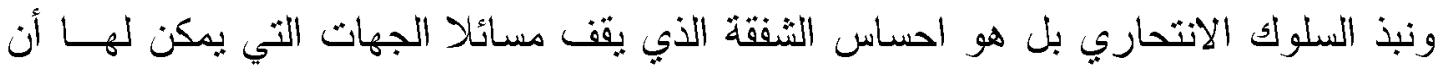

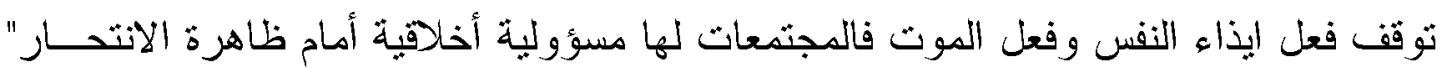
فإذا ما استسلم الفرد لأقل صدمة من صدمات الظروف المحبطة فلأن الحالة التى يكون فيها

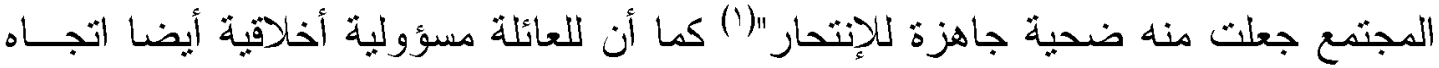

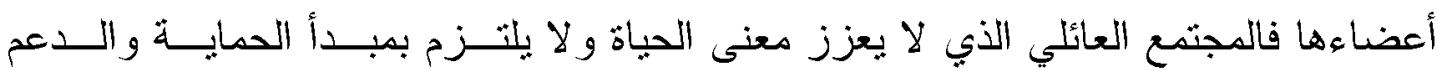
و المساندة لأفر اده من خلال الحب والتواصل ولا بتعهة باعطاء قيم ومعابير التشئئة المنوازنة

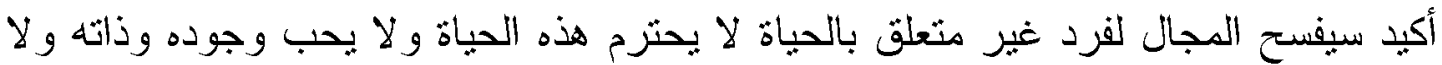

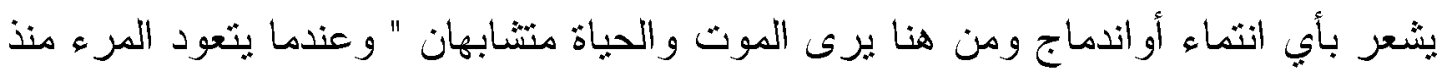

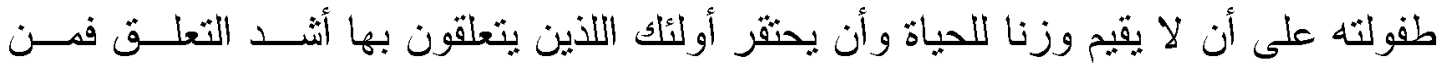

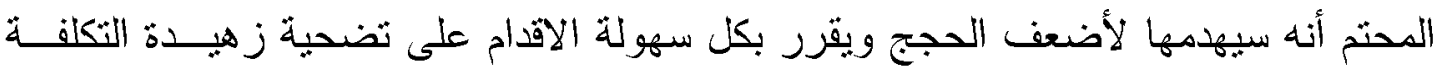

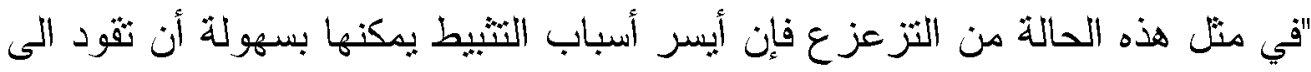

قرارات يائسة فإذا كانت الحياة لا نستحق عناء عيشها فكل شئئ يغدو ذريعة للتخلص منها...

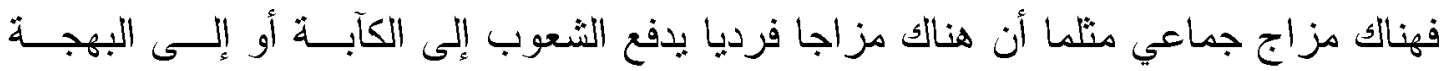
ويجعهم برون الأثباء بألوان زاهية أو معتمة"(") فئل 


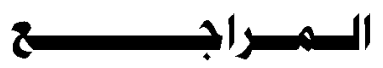

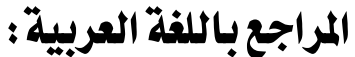

1. إبراهيم عبد الستار،الاكتئاب اضطراب العصر الحديث فهمسهـه وأســائيب علاجـه، دار

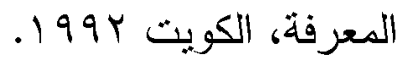

Y. أحمد محمد عبد الخالق (1997) )، قلق الموت، مجلة عالم المعرفة، الكويت ،عدد 111

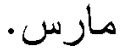

r. آرون بيك (... ب )،العلاج المعرفي والاضطر ابات الانفعالية، ترجمة: دصطفى عادل، بيروت: دار النهضة العربية ـ . ـ. إِيميل دور كايم (د.ت.)، التربية الأخلاقية، نرجمة: بدوي سعيد محمد، مر اجعة وافـي

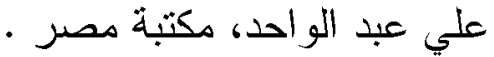

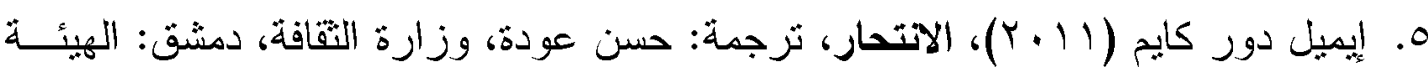

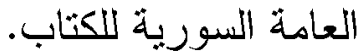

T. كحمد حمدي الحجار (919 19) ،الطب السلوكي المعاصر، بيروت: دار العلم للملايين .

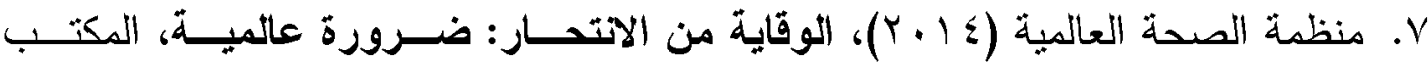

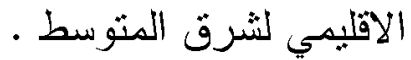

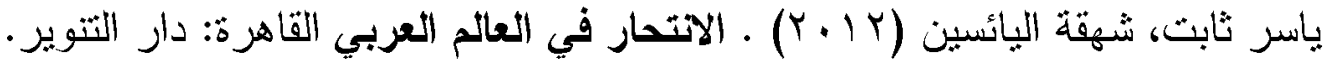

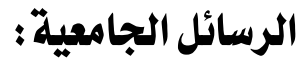

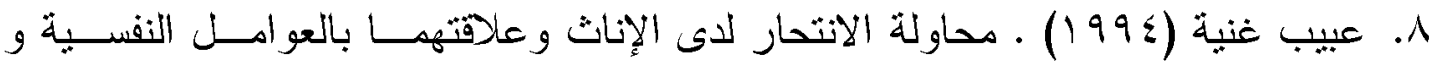
الأسرية، رسالة ماجستير في علم النفس، جامعة الجزائر.

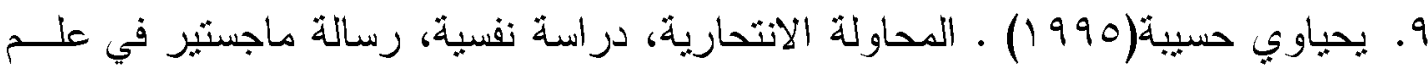

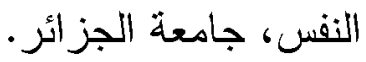
الجرائل الج

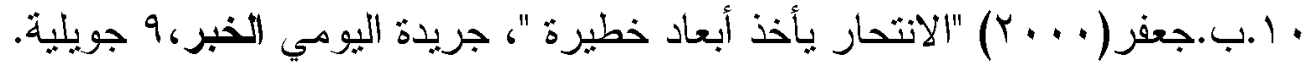

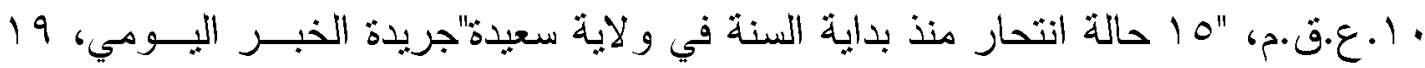

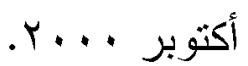




\section{Ouvrages :}

11. BENSMAIL B., La psychiatrie aujourd'hui, OPU, Alger, 1994.

12. DURKHEIM Emile, Le suicide: étude sociologique, $10^{\mathrm{e}}$ édition, PUF, Paris, 1986.

13. Maynard .l, le suicide ,étude normale et métaphysique ,puf .paris.1985.

\section{Revues et périodiques}

14. ANDRIES et AL., «Suicide et conduite a risque », in Revue pratique de psychologie de la vie sociale et d'hygiène mentale, $\mathrm{N}^{\circ} 1,42^{\circ}$ Année, Fédération des associations d'aide à la santé mentale, France, 1996.

15. APTER Alan and al., «Suicidal behavior, Depression and conduct disorder in hospitalized adolescents », in Academy Child PsychoAdol., nº, 1998.

16. BENSMAIL B. et al, «Suicides et conduites suicidaires en milieu maghrebin», in Revue de l'information psychiatrique, vol.66, décembre, Privat, 1990.

17. BOISSON C., «La TS et après? Mise en place d'un réseau d'accompagnement pour les jeunes suicidant de 15 à 25 ans», in Revue pratique de psychologie de la vie sociale et d'hygiène mentale, $\mathrm{n}^{\circ} 2$, vol. 44 , Fédération des associations d'aide à la santé mentale, France, 1998.

18. POMMEREAU Xavier, «Suicide et tentative de suicide chez les adolescents», in Revue pratique de psychologie de la vie sociale et d'hygiène mentale, vol. 44, Fédération des associations d'aide à la santé mentale, France, 1998.

\section{Journaux}

AÏT OUFELIA Mourad, «Benbitour interpellé sur les suicides», in Liberté, $\mathrm{n}^{\circ} 2367,24$ juillet 2000 


\section{Abstract}

Suicide attempt and suicide has become a certain phenomena through the academic and scientific studies done, whether they were local, national or international. Most of scientists have agreed that this phenomena is developing through time, and that is a result of sociological and psychological factors and changes that affect the social and individual structure. From this status, the two researchers try to detect suicide attempt and suicide through analyzing their concepts, trying to study their prevalence, and stop at their root causes (suicide attempt and suicide) through some scientific studies achieved, especially in Algeria. And those dealing with this, at hand phenomena and pointing out some of the factors that enable this phenomena to be studied. 